\title{
Characterization and Classification of Soils of the Terra da Esperança Settlement Project in Chapada do Apodi, Brazil
}

\author{
Joseane Dunga da Costa $^{1}$, Jeane Cruz Portela ${ }^{1}$, Phâmella Kalliny Pereira Farias ${ }^{1}$, Francisco Ernesto Sobrinho ${ }^{1}$, \\ Carolina Malala Martins Souza ${ }^{1}$, Thaís Cristina de Souza Lopes ${ }^{1} \&$ Francisco Wellington Andrade Silva ${ }^{1}$ \\ ${ }^{1}$ Universidade Federal Rural do Semi-Árido, Mossoró, Brazil \\ Correspondence: Jeane Cruz Portela, Universidade Federal Rural do Semi-Árido, Av. Francisco Mota, 572, Bairro \\ Costa e Silva, CEP: 59.625-900, Mossoró, RN, Brazil. Tel: 55-849-96933-669. E-mail: \\ jeaneportela@ufersa.edu.br
}

Received: October 2, 2018

Accepted: January 13, 2019 Online Published: March 15, 2019

doi:10.5539/jas.v11n4p235

URL: https://doi.org/10.5539/jas.v11n4p235

\begin{abstract}
Soil characterization and pedological classification are essential to define its main potentials and restrictions. The objective of this work was to classify the morphological, physical, chemical, and pedological attributes of soils of the Terra da Esperança Settlement Project (TESP) in Chapada do Apodi, Brazil, and find the most sensitive attributes for distinguishing them using multivariate analysis. The research was carried out in the TESP, in the municipality of Governor Dix-Sept Rosado, state of Rio Grande do Norte, Brazil. Ten sites were chosen to open representative soil profiles: Native Forest Area 1 (NFA1), 2 (NFA2), and 3 (NFA3), Collective Area with Native Forest (CNF), Agroecological Area (AEA), Cashew crop Area (CCA) Collective Area with Pasture 1 (CAP1), and 2 (CAP2), Permanent Preservation Area (PPA), and Cajaraneira (Spondia sp.) Orchard Area (COA). Disturbed and undisturbed soil samples were collected and subjected to physical and chemical analysis for soil classification. The soils classes found were: Cambissolo Haplico Carbonatico vertissolico (NFA1), Cambissolo Haplico Carbonatico tipico (CNF, and AEA), Cambissolo Haplico Ta Eutrofico tipico (CAP2, NFA2, and COA), Cambissolo Haplico Ta Eutrofico vertissolico (NFA3), Argissolo Vermelho Distrofico latossolico (CCA), Chernossolo Rendzico Ortico saprolitico (CAP1), and Neossolo Fluvico Ta Eutrofico tipico (PPA). The material of origin of the soils contributed to the presence of a calcic horizon in the profiles NFA1, CNF, AEA, CCA (Cambissolos), and CAP1 (Chernossolos). The textural class of the soils varied from sand to clay. The Argissolo (CCA) presented acid character, high aluminum saturation, low base saturation, dystrophic character, and low cation exchange capacity, forming horizons with chemical limitations, due to its latossolico character. The most sensitive attributes for distinguishing the soil classes were related to the source material, which directly influenced the soil physical (silt and clay) and chemical (acidity, salinity, nutrient availability, and clay activity) attributes.
\end{abstract}

Keywords: Jandaira Formation, pedogenesis, semiarid, agricultural sustainability

\section{Introduction}

The Chapada do Apodi geological formation encompasses twelve municipalities-Apodi, Baraúna, Felipe Guerra, Governador Dix-Sept Rosado, Mossoro, Upanema, and Assu in the state of Rio Grande do Norte, and Alto Santo, Jaguaruana, Limoeiro do Norte, Quixeré, and Tabuleiro do Norte in the state of Ceara, Brazil. It is part of the Potiguar basin, whose stratigraphic units are predominantly represented by limestones of the Jandaira Formation at the top, and sandstones of the Açu Formation at the base (Pessoa Neto et al., 2007).

The spatial variability of the soil attributes of the Chapada do Apodi is probably due to its different micro-relieves and water flows (Costa et al., 2011; Oliveira et al., 2009). This explains its soil diversity, which includes Cambissolos, Chernossolos, and Neossolos Fluvicos in the fluvial plain formed by sediments from Cretaceous rocks of the Apodi group (Maia, 2005; Melo et al., 2017), and Argissolos, Latossolos, and Neossolos Quartzarenicos in the flat landscape formed from sandstones of the Açu Formation (Ernesto Sobrinho, 1980).

Since the occupation of the land by the settlers, the disorderly agricultural exploitation has changed significantly the organization and promoted degradation of this rural area in the Chapada do Apodi microregion, which is an important agricultural region in the Northeast of Brazil (Mota et al., 2007). This was the result of erosion due to the non-observance of agricultural suitability or land use capacity, intensive land use without maintenance of soil 
plant cover, and absence of conservation practices. These problems were aggravated by the lack of previous studies in this region and have drawn the attention of the academic community, especially those directly involved with environmental impacts of land and water uses, and agro-environmental planning of rural settlements.

In this context, the characterization and analysis of soil morphological, physical, and chemical properties, and pedological classification are important to define the main potentials and restrictions of these soils (Melo et al., 2017). They are indispensable tools for the planning of the land use and occupation, and the sustainability of agricultural soils.

Therefore, the objective of this work was to classify the morphological, physical, chemical, and pedological attributes of soils of the Terra da Esperança Settlement Project (TESP) in Chapada do Apodi, Brazil, and find the most sensitive attributes for distinguishing them using multivariate analysis.

\section{Material and Methods}

\subsection{Study Area}

The research was carried out in the Terra da Esperança Settlement Project (TESP), in the municipality of Governor Dix-Sept Rosado $\left(05^{\circ} 27^{\prime} 324^{\prime \prime}\right.$ S, 37 31'15.6" W), West Potiguar mesoregion, Chapada do Apodi microregion, state of Rio Grande do Norte, Brazil (Figure 1). This municipality covers an area of $1,263 \mathrm{~km}^{2}$. The region presents a BSh, hot semiarid climate, according to Köppen classification (Alvares et al., 2013); annual mean precipitation of $712 \mathrm{~mm}$, with rainfall concentration from February to May; natural vegetation of hyper-xerophilous Caatinga, and varied classes of soils. According to the Soil Exploration-Reconnaissance Survey of the state of Rio Grande do Norte (Jacomine et al., 1971), the soils found in this municipality are Cambissolos, Vertissolos, and Chernossolos. The study area has predominant flat relief (DNOCS, 1978), however, with different micro-relieves, varying from slightly undulated to undulated (Valeriano \& Rossetti, 2008).

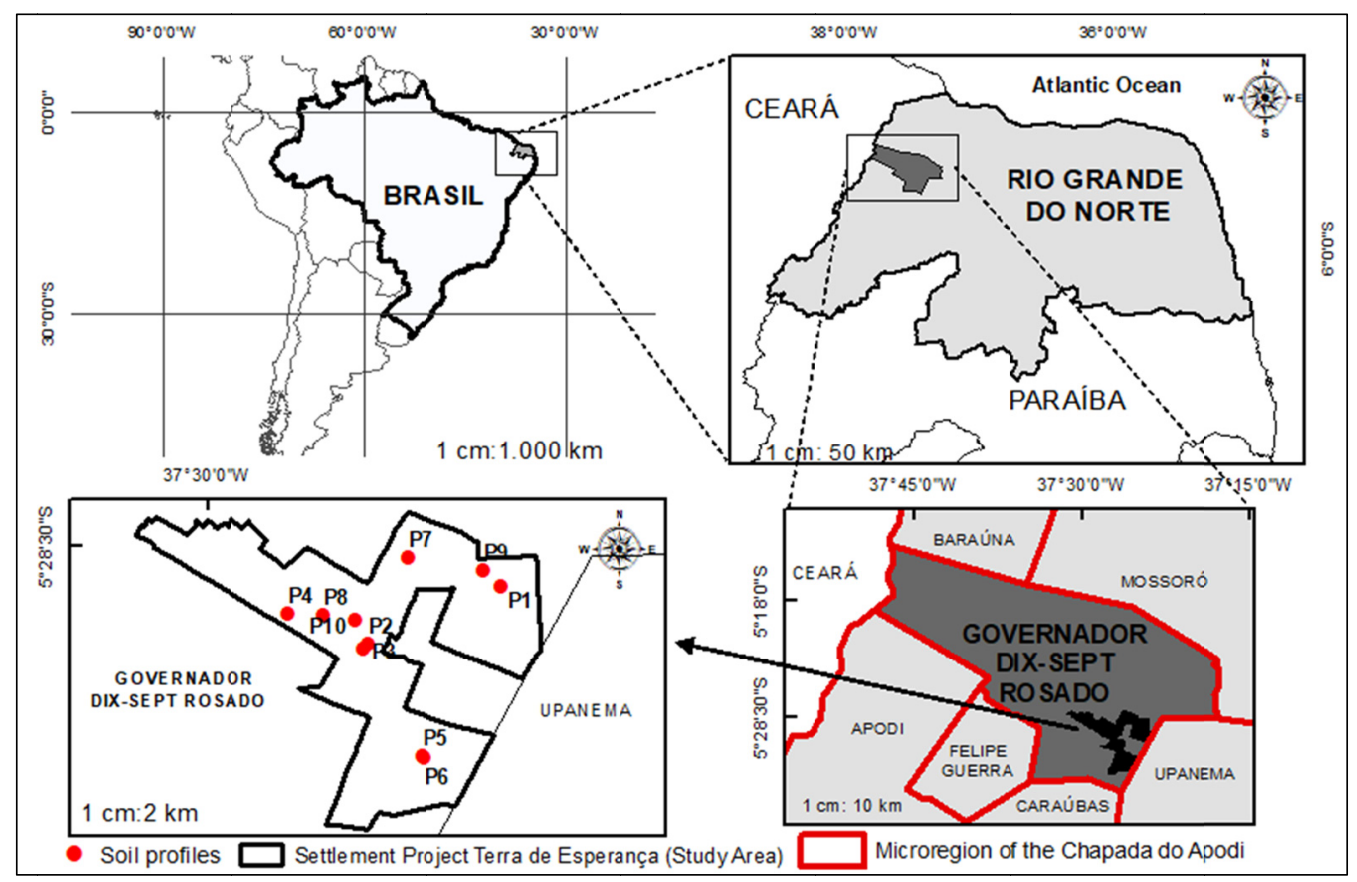

Figure 1. Location of the study area-Terra da Esperança Settlement Project (TESP), Governor Dix-Sept Rosado, Chapada do Apodi microregion, state of Rio Grande do Norte, Brazil

The TESP is in the edge of the limestone plateau of Governador Dix-Sept Rosado, at $12 \mathrm{~km}$ from the city's downtown, and has an area of 6.297 ha. It is divided into three agro-villages with 113 family farmers who have 30 hectares each. These farmers were settled in 1998; the land was granted by the National Institute of Colonization and Agrarian Reform (INCRA). 
Ten sites were chosen to open representative soil profiles: Native Forest Area 1 (NFA1), 2 (NFA2), and 3 (NFA3), Collective Area with Native Forest (CNF), Agroecological Area (AEA), Cashew crop Area (CCA) Collective Area with Pasture 1 (CAP1) and 2 (CAP2), Permanent Preservation Area (PPA), and Cajaraneira (Spondia sp.) Orchard Area (COA).

The NFA1, NFA2, and NFA3 were in an environmental reserve with preserved hyper-xerophilous Caatinga vegetation, and vegetation with deciduous species, however, some wood had been removed for fencing of other areas. These areas were reference areas because of the low anthropogenic influence on them.

The CNF had a preserved hyper-xerophilous Caatinga vegetation next to a crop area with soil conventional management (CCA).

The AEA was delineated and implemented in 2005. The use of this area was defined by the settlers, who intended to produce fruits and forage on it to meet the needs of local families and animals. This area presented some agro-ecological practices of soil conservation, and honey production by Africanized bees.

The CCA had cashew crops intercropped with the hyper-xerophilous Caatinga native vegetation, using traditional managements.

The CAP1, and CAP2 were natural pasture areas for goats reared by the settlers. CAP2 naturally presented accumulation of water in rainy periods due to its low altitude, and it was mechanically excavated by the settlers to provide water for the animals.

The PPA had outcropping and accumulation of water in rainy periods. It was in the lowest point of the landscape and, therefore, an area of deposition of sediments.

The COA had cajaneiras, species of the genus Spondia, which were planted by the former owner in the 1970s. This species had great economic importance for the settlers due to its great production of fruits. In the dry season, this area presents a great input of organic matter to the soil due to the leaf loss of this species.

\subsection{Pedological Classification}

Ten representative soil profiles were opened, one in each study site. The profile opening locations were chosen based on photointerpretation of satellite images (Google Earth Pro) from 2002 to 2016, considering the different soil shades, which were confirmed in field. The morphological analysis consisted of descriptions of soil order, depth, transition between horizons, color (Munsell chart), structure, and consistency (Santos et al., 2006). Physical and chemical analyzes were performed to obtain the soil taxonomic classification up to the fourth categorical level, according to the Brazilian Soil Classification System (SiBCS) (Santos et al., 2013, Teixeira et al., 2017). The soil profiles were georeferenced, including altitude, using a GPS device (GPSMAP GARMIN $64 \mathrm{~s})$.

\subsection{Collection and Preparation of Samples}

Disturbed and undisturbed soil samples were collected from all horizons of the representative profiles. The samples were placed in identified plastic bags and taken to the Laboratory of Soil, Water and Plant Analysis of the Agricultural Sciences Center of the Federal Rural University of the Semiarid Region (LASAP/CCA/UFERSA). Undisturbed samples were collected using four volumetric rings with height of $5.0 \mathrm{~cm}$ and diameter of $5.0 \mathrm{~cm}$. Disturbed samples were air-dried, disaggregated and passed through $20 \mathrm{~mm}$, and $2 \mathrm{~mm}$ mesh sieves to obtain the gravel fraction $\left(>2.00 \mathrm{~mm}\right.$ to $<20.00 \mathrm{~mm}$ ) by washing them with a NaOH $1 \mathrm{~mol} \mathrm{~L}^{-1}$ and distilled water solution, and the air-dried fine earth (ADFE) $(<2.00 \mathrm{~mm}$ ), according to Teixeira et al. (2017).

\subsection{Physical and Chemical Analyzes}

The results of the physical and chemical analyzes were expressed as means of three replications. The soil granulometry and particle density (ADFE) was evaluated using disturbed samples, and soil density was evaluated using undisturbed samples, according to Teixeira et al. (2017).

The soil chemical analysis was performed according to Teixeira et al. (2017) using the ADFE. The soil attributes evaluated were $\mathrm{pH}$ in water at ratio of 1:2.5 (soil:water), and in $\mathrm{KCl} ; \mathrm{Ca}^{2+}, \mathrm{Mg}^{2+}$, and exchangeable $\mathrm{Al}^{3+}$ extracted with $\mathrm{KCl} 1 \mathrm{~mol} \mathrm{~L}^{-1}$ and analyzed by titration; potential acidity $(\mathrm{H}+\mathrm{Al})$, using calcium acetate; available $\mathrm{P}, \mathrm{Na}^{+}$, and $\mathrm{K}^{+}$, using the Mehlich 1 extractor, analyzes by colorimetry, and flame photometry, respectively; electrical conductivity of the soil saturation extract in water (EC), using a conductivity meter, and calcium carbonate equivalent. Subsequently, the delta $\mathrm{pH}$, sum of bases (SB), effective cation exchange capacity (t); cation exchange capacity at $\mathrm{pH} 7.0(\mathrm{~T})$, base saturation $(\mathrm{V} \%)$, exchangeable aluminum saturation $(\mathrm{m} \%)$, exchangeable sodium percentage (ES \%), and clay activity were calculated. Total organic carbon (TOC) was 
determined by the titration of the remaining $0.167 \mathrm{~mol} \mathrm{~L}^{-1}$ potassium dichromate with ammoniacal ferrous sulfate after the wet oxidation process (Yeomans \& Bremner, 1988).

\subsection{Soil Class Mapping of the Terra da Esperança Settlement Project}

The photointerpretation of the soil shades from the satellite images of the TESP perimeter, which was defined by the shapefile of the INCRA, was carried out using vector files in KML format manually vectorized and later converted into shapefile in the Geographic Information System (GIS) Qgis 2.8.9, in WGS 84 Datum. Field surveys of the areas with different soil shades were performed to identify their boundaries and georeferencing them for a better precision, and the opening of the profiles for pedological classification. After defining the shapes of the different soils, their predominant soil classes were determined. These shapes were converted to the cartographic projection UTM 24S, generating a map of their respective areas in hectare.

\subsection{Statistical Analysis}

Soil profiles were statistically analyzed using multivariate analysis techniques-Pearson's correlation, Factorial Analysis, and Principal Component Analysis (PCA) - in the Statistica 7.0 program (StatSoft, 2004), considering chemical $\left(\mathrm{CaCO}_{3}, \mathrm{TOC}, \mathrm{pH}\right.$ in water, $\mathrm{pH}$ in $\left.\mathrm{KCl}, \Delta \mathrm{pH}, \mathrm{EC}, \mathrm{P}, \mathrm{K}^{+}, \mathrm{Na}^{+}, \mathrm{Ca}^{2+}, \mathrm{Mg}^{2+}, \mathrm{Al}^{3+}, \mathrm{H}+\mathrm{Al}\right)$, and physical (sand, silt, clay, T, V, and ES \%) attributes).

\section{Results and Discussion}

\subsection{Pedagogical Classification}

The classification of the soils of the profiles, evaluated up to the fourth categorical level according to the Brazilian Soil Classification System (SiBCS) (Santos et al., 2013; Teixeira et al., 2017), showed the classes Cambissolo Haplico Carbonatico vertissolico (NFA1), Cambissolo Haplico Carbonatico tipico (CNF and AEA), Cambissolo Haplico Ta Eutrofico tipico (CAP2, NFA2, and COA), Cambissolo Haplico Ta Eutrofico vertissolico (NFA3), Argissolo Vermelho Distrofico latossolico (CCA), Chernossolo Rendzico Ortico saprolitico (CAP1), and Neossolo Fluvico Ta Eutrofico tipico (PPA).

According to the soil classes found in this geological formation (Chapada do Apodi), the predominant class in this region is Cambissolo. Jarbas et al. (2018) also found a great extension of this class in parts of the states of Rio Grande do Norte and Ceara, in Brazil. Soils of this class originated from the Jandaira Formation, and consist of layers of light gray to white or yellow calcite limestones of fine to medium granulation, and gray or yellow dolomitic limestones of coarser granulation (Mota et al., 2007), and other homogeneous formation factors. However, the area also presented Argissolos, Chernossolos, and Neossolos, complementing the Soil Exploration-Reconnaissance Survey of the state of Rio Grande do Norte (Jacomine et al., 1971), which found only Cambissolos in the study area due to its work scale.

The taxonomic classification showed all Cambissolos classified as Haplicos at the second categorical level because they did not fit to the other classes in this level, i.e., due to absence of other differential properties. The third categorical level of the soil profiles NFA1, CNF, and AEA were Carbonatico, because they presented a calcium horizon within the $120 \mathrm{~cm}$ soil layer, characterized by the accumulation of calcium carbonate in the $\mathrm{C}$ horizon, containing at least $150 \mathrm{~g} \mathrm{~kg}^{-1}$ of calcium, and with width of at least $15 \mathrm{~cm}$, due to the pedogenetic process of calcification (Table 3) (Santos et al., 2013). The other profiles (CAP2, NFA2, NFA3, and COA) were classified as Ta Eutrofico because they presented high clay activity, i.e., equal to or greater than $27 \mathrm{cmol} \mathrm{^{-1 }}$ of clay, and saturation by bases greater than $50 \%$, at least on the B horizon. The fourth classification level showed the profiles CNF, AEA, CAP2, NFA2, and COA classified as tipico because they did not present any restrictive characteristic for this level. The profiles NFA1 and NFA3 were classified as vertissolico, since a vertic horizon was noticeable, consisting of a subsurface mineral horizon that presents cracks in dry periods of the year due to the expansion and contraction of clays, with at least $1 \mathrm{~cm}$ of width, and it presented slinckensides in the profile NFA3, which are smooth surfaces of friction, also caused by the expansion and contraction of clays (Tabela 2) (Santos et al., 2013).

The Argissolo in the CCA profile was classified up to the fourth categorical level as Argissolo Vermelho Distrofico latossolico (PVd) because it presented a 2.5YR soil shade and basal saturation of less than $50 \%$ in most of the $100 \mathrm{~cm}$ of the B horizon (including the BA horizon), and presence of a latossolico B horizon (formed by the latolization process) below the textural diagnostic $\mathrm{B}$ horizon within the $150 \mathrm{~cm}$ soil layer, and textural $\mathrm{B}$ to A ratio greater than 1.8, which differentiated this soil class from the Latossolo class. Moreover, it was the profile with the highest altitude $(97 \mathrm{~m})$ (Tables 1 and 3).

The Chernossolo in the CAP1 profile was classified as Chernossolo Rendzico Ortico saprolitico (MDo), due to its chernozemic A horizon (Ak), calcic horizon coinciding with the Ak horizon and $\mathrm{C}$ horizon, and no restrictive 
characteristic for the third categorical level, presenting a mild $\mathrm{Cr}$ horizon, and absence of lytic contact within the $100 \mathrm{~cm}$ soil layer.

The Neossolo of the PPA profile was classified as Neossolo Fluvico Ta Eutrofico tipico (RYve) due to the presence of alluvial sediments, and A horizon over the $\mathrm{C}$ horizon, and its fluvic character within the $150 \mathrm{~cm}$ soil layer, since the area is characterized by outcrop of water in rainy periods and a lower altitude (74 $\mathrm{m}$ ) (Table 1); this is a permanent preservation area because of this characteristic. Moreover, it presented high clay activity, and saturation by bases greater than $50 \%$ in most of the $\mathrm{C}$ horizon within the $120 \mathrm{~cm}$ soil layer, and it was classified as tipico because it did not fit to other classes of the fourth categorical level.

\subsection{Morphological Attributes}

The Cambissolos found were mineral soils derived from Jandaira limestones from the Cretaceous Period, presenting an incipient diagnostic B horizon (Bi). In general, they were shallow soils, especially CAP2, which had depth of $27 \mathrm{~cm}$ (Table 1), and present clear and flat transitions between surface horizons.

The profiles NFA1, CNF, AEA, CAP2, NFA2, NFA3, and COA did not present significant differences in color, with hue angles ranging from 7.5YR to $10 \mathrm{YR}$, except NFA1 and NFA3, which presented differences in deeper horizons, with $2.5 \mathrm{Y}$, and yellowish shades in all horizons.

The structure of almost all profiles showed subangular blocks; the soil of the profiles PPA (Neossolo), NFA3, and COA (Cambissolos) disintegrate in granules.

The wet and dry consistencies of all profiles were similar, varying from friable to very friable, and from soft to slightly hard, respectively, with variation in consistency in subsurface (friable to firm, slightly hard to hard, hard to very hard), except the profiles CNF and CAP2 (Cambissolos). The wet consistency was slightly plastic to plastic, and slightly sticky to sticky. However, the Argissolo was the only soil that did not present plasticity and stickiness in the surface layer due to its sandy texture (Table 3). Large size particles of coarse sands have low specific surface area, little capacity to adsorb water and nutrients, and do not adhere to each other forming a coherent mass (Brady \& Weil, 2013).

The Argissolo Vermelho Distrofico latossolico (CCA) is a mineral soil derived from sandstones of the Açu Formation, with a textural diagnostic B horizon (Bt). It is a well-developed and deep soil, which contributes to a diffuse flat transition between its horizons, and has reddish color with shades ranging from 5YR (surface layer) to $2.5 \mathrm{YR}$ (deeper layers).

Table 1. Morphological attributes of representative soil profiles of the Terra da Esperança Settlement Project, in Governor Dix-Sept Rosado, RN, Brazil

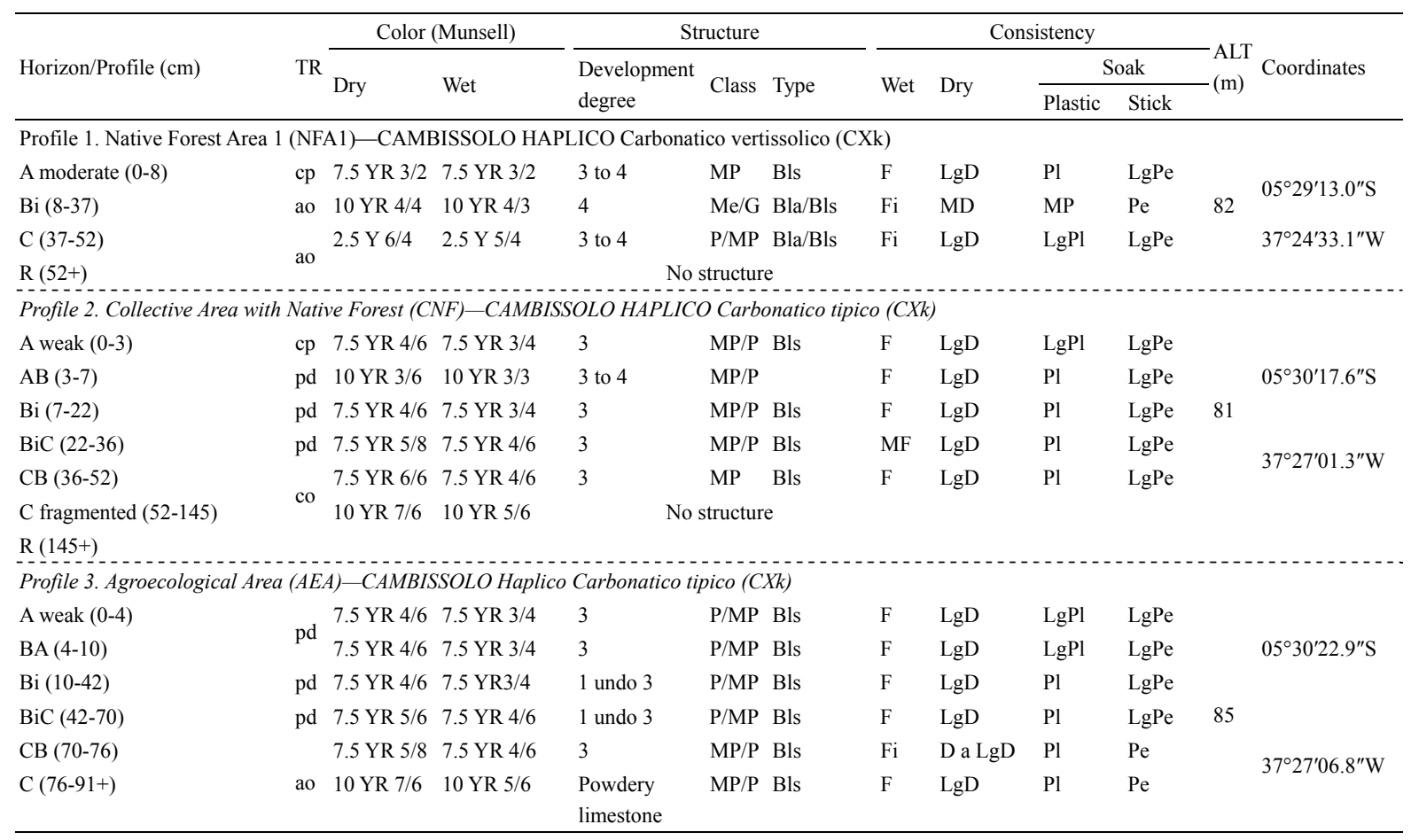




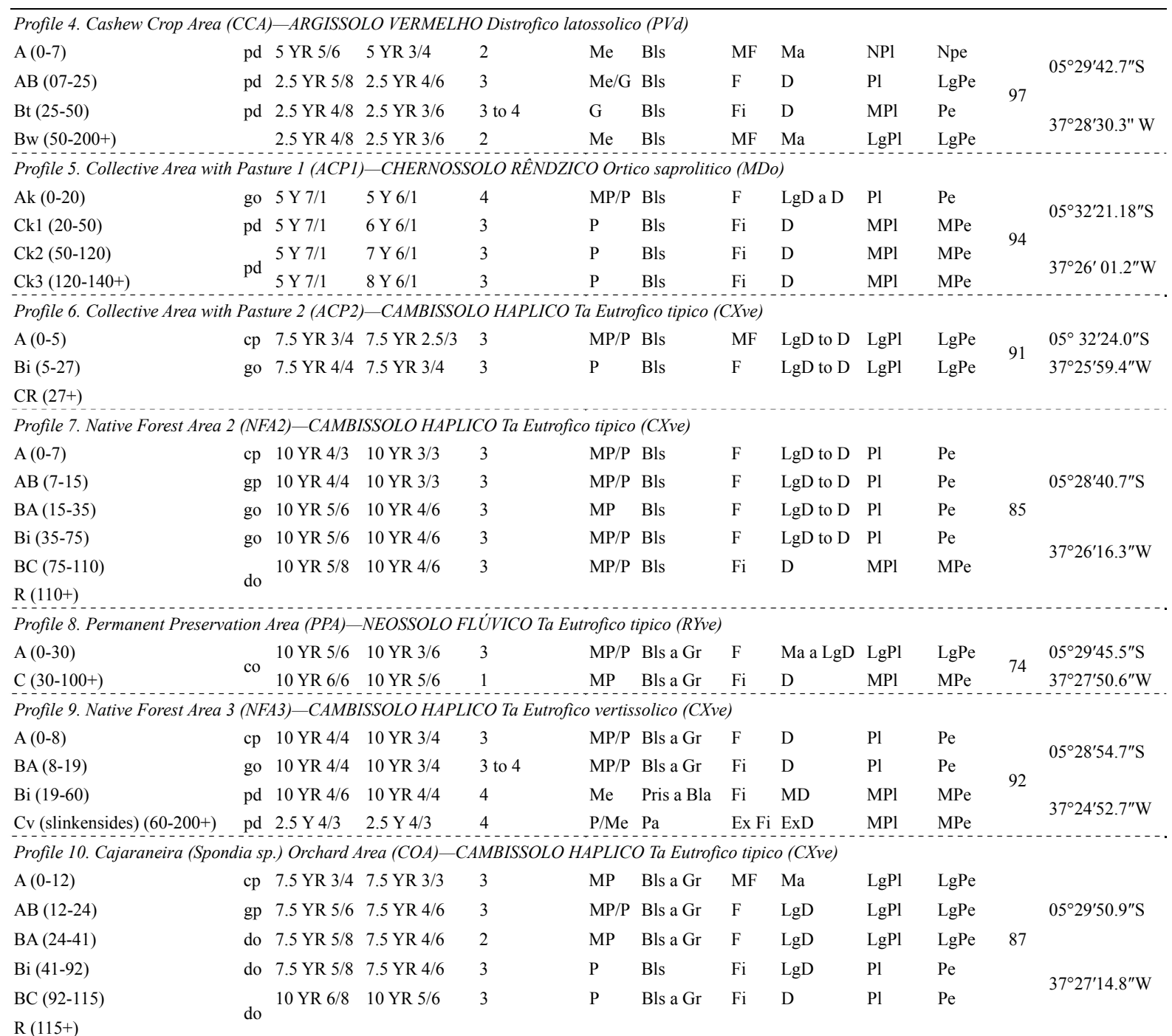

Note. $\mathrm{TR}=$ Transition: $\mathrm{a}=$ abrupt, $\mathrm{c}=$ clear, $\mathrm{g}=$ gradual, $\mathrm{d}=$ diffuse, $\mathrm{p}=$ flat, $\mathrm{o}=$ wavy. Structure: $1=$ solid, $2=$ weak, 3 = moderate; 4 = strong, $\mathrm{P}=$ small, $\mathrm{Me}=$ average, $\mathrm{G}=$ large, $\mathrm{Gr}=$ granular, $\mathrm{Bla}=$ angular blocks, $\mathrm{Bls}=$ subangular blocks, Pris $=$ prismatic, $\mathrm{PA}=$ Paralepidid; Consistency: $\mathrm{Ma}=$ soft, $\mathrm{D}=$ hard, $\mathrm{F}=$ friable, $\mathrm{MF}=$ very friable, $\mathrm{Fi}=$ firm, $\mathrm{Ex}=$ extremely, $\mathrm{N}=\mathrm{No}, \mathrm{M}=$ very, $\mathrm{Lg}=$ slightly, $\mathrm{Pl}=$ plastic, $\mathrm{Pe}=$ Sticky. $\mathrm{ALT}=$ Altitude .

The other soils presented no clear chroma as the Chernossolo Rendzico (CAP1), with lighter greyish colors, denoting accumulation of $\mathrm{CaCO}_{3}$ and its effect from surface to deep layers, and lighter and purer color in the Neossolo Fluvico (PPA). This soil is characterized by the influence of alluvial sediments from Cretaceous rocks of the Apodi group (Maia, 2005) and sediments from erosion of surrounding soils in higher altitudes that are deposited in the Barreiro watershed.

\subsection{Physical Attributes}

According to the distribution of the particle size that shows the physical attributes of the profiles (Table 2), the highest clay contents in the surface layer were found in the profiles NFA1, NFA2, NFA3, and COA (Cambissolos Haplicos), ranging from $360 \mathrm{~g} \mathrm{~kg}^{-1}$ to $408 \mathrm{~g} \mathrm{~kg}^{-1}$, and in the PPA (Neossolo Fluvico) (550 g kg area of sediment deposition and groundwater oscillations and present sandy clay, and clay loam to clay textures.

Souza et al. (2015) evaluate physical and chemical properties of a Cambissolo Eutrofico under different agricultural uses in the Chapada do Apodi and found predominance of the clay fraction in areas with native forests, and Spondia sp., with similar values ranging from 373 to $478 \mathrm{~g} \mathrm{~kg}^{-1}$. However, the clay fraction increased in depth, mainly in the Argissolo (CCA), presenting accumulation of clay of $422 \mathrm{~g} \mathrm{~kg}^{-1}$ in the $25-50 \mathrm{~cm}$ layer, denoting the evolution to a textural $\mathrm{B}$ horizon $(\mathrm{Bt}$ ) formed by the pedogenic process of argiluviation (Table 2). 
The Argissolo Vermelho (CCA) had the highest sand content in the A horizon ( $\left.894 \mathrm{~g} \mathrm{~kg}^{-1}\right)$, showing sandy, and sandy clay loam to sandy clay textures along the profile (Table 2). Its higher soil and particle densities are explained by the sand fraction, due to the dominance of quartz; solid particles in coarser soils are less susceptible to aggregate formation, and these soils have normally higher density than fine-texture soils (Brady \& Weil, 2013).

The Bt horizon of the Argissolo (CCA) presented higher clay content than the A horizon (Table 2). This was expected due to the soil class, and its sandy clay texture. The lowest silt to clay ratio found in this soil denoted its more weathered condition in depth.

The Chernossolo Rendzico had the highest silt contents, ranging from $593 \mathrm{~g} \mathrm{~kg}^{-1}$ (chernozemic A horizon) to 642 $\mathrm{g} \mathrm{kg}^{-1}$ (C horizon), presenting silt loam texture (Table 2). This was due to the strong influence of the source material (Jandaira limestone), which contributed to its higher silt to clay ratio (2.52 to 3.42) compared to the other soil classes, and indicates a low weathering degree. Similar results were found by Melo et al. (2017), who attributed these results to the fossiliferous limestone (low-weathered source material that can originate different soils), and its fine granulation; they found silt to clay ratios ranging from 3.00 to 6.00 .

The highest degrees of flocculation were found for the Neossolo Fluvico (PPA) (Table 2), in the A horizon $(24.76 \%)$, and for the Chernossolo Rendzico ( $\mathrm{Ak}=34.65 \%$, and $\mathrm{Ck} 1=36.49 \%)$; these results were probably influenced by the silt and clay fractions, and the exchangeable bases $\mathrm{Ca}^{2+}$ and $\mathrm{Mg}^{2+}$ (Table 3).

Table 2. Physical attributes of representative soil profiles of the Terra da Esperança Settlement Project, in Governor Dix-Sept Rosado, RN, Brazil

\begin{tabular}{|c|c|c|c|c|c|c|c|c|c|c|c|c|}
\hline \multirow[b]{2}{*}{ Horizon/Profile } & \multicolumn{6}{|c|}{ Particle size } & \multirow[b]{2}{*}{ CDW } & \multirow[b]{2}{*}{ DF } & \multirow{2}{*}{$\begin{array}{l}\text { Silt to } \\
\text { clay ratio }\end{array}$} & \multirow{2}{*}{$\begin{array}{l}\text { Textural } \\
\text { Classification } \\
(\mathrm{SiBCS})\end{array}$} & \multirow[b]{2}{*}{$\mathrm{Dp}$} & \multirow[b]{2}{*}{ Ds } \\
\hline & Gravel & $\begin{array}{l}\text { Coarse } \\
\text { sand }\end{array}$ & $\begin{array}{l}\text { Fine } \\
\text { sand }\end{array}$ & $\begin{array}{l}\text { Total } \\
\text { sand }\end{array}$ & Silt & Clay & & & & & & \\
\hline -------------- cm ------------- & $\%$ & \multicolumn{6}{|c|}{------------------- $\mathrm{g} \mathrm{kg}^{-1}$------------------ } & \multicolumn{3}{|l|}{$\%$} & \multicolumn{2}{|c|}{$---\mathrm{g} \mathrm{cm}^{-3}---$} \\
\hline \multicolumn{13}{|c|}{ Profile 1. Native Forest Area 1 (NFA1)_CAMBISSOLO HAPLICO Carbonatico vertissolico (CXk) } \\
\hline A moderate $(0-8)$ & 2.2 & 247 & 221 & 468 & 172 & 360 & 292 & 18.87 & 0.48 & Sandy clay & 2.23 & 0.96 \\
\hline $\mathrm{Bi}(8-37)$ & 5.5 & 292 & 142 & 434 & 113 & 453 & 365 & 19.30 & 0.25 & Clay & 2.14 & 1.23 \\
\hline $\mathrm{C}(37-52)$ & 32.4 & 616 & 26 & 642 & 106 & 252 & 174 & 30.95 & 0.42 & Sandy clay loam & 2.44 & 1.31 \\
\hline \multicolumn{13}{|l|}{$\mathrm{R}(52+)$} \\
\hline \multicolumn{13}{|c|}{ Profile 2. Collective Area with Native Forest (CNF)—CAMBISSOLO HAPLICO Carbonatico tipico (CXk) } \\
\hline A weak $(0-3)$ & 2.5 & 384 & 236 & 620 & 130 & 250 & 199 & 20.40 & 0.52 & Sandy clay loam & 2.34 & 1.39 \\
\hline $\mathrm{AB}(3-7)$ & 4.0 & 397 & 209 & 606 & 130 & 264 & 245 & 7.36 & 0.49 & Sandy clay loam & 2.35 & 1.56 \\
\hline $\mathrm{Bi}(7-22)$ & 3.6 & 312 & 198 & 510 & 146 & 344 & 251 & 27.14 & 0.42 & Sandy clay loam & 2.52 & 1.43 \\
\hline $\mathrm{BiC}(22-36)$ & 4.0 & 297 & 180 & 477 & 192 & 331 & 230 & 30.59 & 0.58 & Sandy clay loam & 2.73 & 1.53 \\
\hline CB (36-52) & 3.3 & 300 & 155 & 455 & 211 & 334 & 224 & 32.95 & 0.63 & Sandy clay loam & 2.49 & 1.54 \\
\hline $\mathrm{C}$ fragmented (52-145) & 33.9 & 180 & 110 & 290 & 600 & 110 & 102 & 7.27 & 5.45 & Silt loam & 2.71 & - \\
\hline \multicolumn{13}{|l|}{$\mathrm{R}(145+)$} \\
\hline \multicolumn{13}{|c|}{ Profile 3. Agroecological Area (AEA)—CAMBISSOLO Haplico Carbonatico tipico (CXk) } \\
\hline A weak $(0-4)$ & 2.0 & 515 & 176 & 691 & 90 & 219 & 188 & 14.16 & 0.41 & Sandy clay loam & 2.69 & 1.53 \\
\hline $\mathrm{BA}(4-10)$ & 2.7 & 524 & 155 & 679 & 77 & 244 & 209 & 14.34 & 0.32 & Sandy clay loam & 2.73 & 1.59 \\
\hline Bi (10-42) & 1.7 & 379 & 208 & 587 & 167 & 246 & 239 & 2.85 & 0.68 & Sandy clay loam & 2.58 & 1.48 \\
\hline $\mathrm{BiC}(42-70)$ & 1.6 & 331 & 208 & 539 & 206 & 255 & 233 & 8.63 & 0.81 & Sandy clay loam & 2.65 & 1.49 \\
\hline CB (70-76) & 1.7 & 324 & 195 & 519 & 207 & 274 & 245 & 10.58 & 0.76 & Sandy clay loam & 2.57 & - \\
\hline C (76-91+) & 7.8 & 564 & 110 & 674 & 62 & 264 & 237 & 10.23 & 0.23 & Sandy clay loam & 2.81 & - \\
\hline \multicolumn{13}{|c|}{ Profile 4. Cashew Crop Area (CCA)_ARGISSOLO VERMELHO Distrofico latossolico (PVd) } \\
\hline $\mathrm{A}(0-7)$ & 4.8 & 224 & 670 & 894 & 36 & 70 & 56 & 20.50 & 0.51 & Sand & 2.43 & 1.38 \\
\hline $\mathrm{AB}(07-25)$ & 4.0 & 410 & 225 & 635 & 50 & 315 & 258 & 18.11 & 0.16 & Sandy clay loam & 2.42 & 1.50 \\
\hline $\mathrm{Bt}(25-50)$ & 3.8 & 348 & 180 & 528 & 50 & 422 & 221 & 47.73 & 0.12 & Sandy clay & 2.45 & 1.42 \\
\hline $\mathrm{Bw}(50-200+)$ & 3.9 & 374 & 243 & 617 & 101 & 282 & 175 & 37.98 & 0.36 & Sandy clay loam & 2.54 & 1.29 \\
\hline \multicolumn{13}{|c|}{ Profile 5. Collective Area with Pasture 1 (ACP1)—CHERNOSSOLO RENDZICO Ortico saprolitico (MDo) } \\
\hline $\operatorname{Ak}(0-20)$ & 4.1 & 54 & 149 & 203 & 593 & 204 & 133 & 34.65 & 2.92 & Silt loam & 2.45 & 1.32 \\
\hline Ck1 (20-50) & 2.4 & 46 & 128 & 174 & 604 & 222 & 141 & 36.49 & 2.72 & Silt loam & 2.52 & 1.23 \\
\hline Ck2 (50-120) & 2.4 & 49 & 149 & 198 & 574 & 228 & 165 & 27.66 & 2.52 & Silt loam & 2.63 & 1.37 \\
\hline Ck3 (120-140+) & 1.8 & 42 & 128 & 170 & 642 & 188 & 134 & 28.67 & 3.42 & Silt loam & 2.47 & 1.28 \\
\hline
\end{tabular}




\begin{tabular}{|c|c|c|c|c|c|c|c|c|c|c|c|c|}
\hline \multicolumn{13}{|c|}{ Profile 6. Collective Area with Pasture 2 (ACP2)_CAMBISSOLO HAPLICO Ta Eutrofico tipico (CXve) } \\
\hline$A(0-5)$ & 18.1 & 373 & 180 & 553 & 133 & 314 & 228 & 27.39 & 0.42 & Sandy clay loam & 2.55 & 1.24 \\
\hline $\mathrm{Bi}(5-27)$ & 18.0 & 315 & 193 & 508 & 112 & 380 & 323 & 15.03 & 0.29 & Sandy clay & 2.78 & 1.10 \\
\hline \multicolumn{13}{|l|}{$\mathrm{CR}(27+)$} \\
\hline \multicolumn{13}{|c|}{ Profile 7. Native Forest Area 2 (NFA2)—CAMBISSOLO HAPLICO Ta Eutrofico tipico (CXve) } \\
\hline $\mathrm{A}(0-7)$ & 3.6 & 337 & 158 & 495 & 97 & 408 & 336 & 17.67 & 0.24 & Sandy clay & 2.42 & 1.33 \\
\hline $\mathrm{AB}(7-15)$ & 4.2 & 278 & 160 & 438 & 143 & 419 & 368 & 12.12 & 0.34 & Clay & 2.41 & 1.18 \\
\hline $\mathrm{BA}(15-35)$ & 3.5 & 246 & 156 & 402 & 134 & 464 & 433 & 6.72 & 0.29 & Clay & 2.32 & 1.22 \\
\hline Bi (35-75) & 3.8 & 242 & 151 & 393 & 154 & 453 & 346 & 23.56 & 0.34 & Clay & 2.46 & 1.40 \\
\hline BC (75-110) & 6.8 & 255 & 121 & 376 & 144 & 480 & 370 & 23.00 & 0.30 & Clay & 2.55 & - \\
\hline \multicolumn{13}{|l|}{$\mathrm{R}(110+)$} \\
\hline \multicolumn{13}{|c|}{ Profile 8. Permanent Preservation Area (PPA)—NEOSSOLO FLÚVICO Ta Eutrofico tipico (RYve) } \\
\hline $\mathrm{A}(0-30)$ & 1.3 & 186 & 133 & 319 & 131 & 550 & 414 & 24.76 & 0.24 & Clay & 2.30 & 1.12 \\
\hline $\mathrm{C}(30-100+)$ & 1.6 & 193 & 132 & 325 & 118 & 557 & 453 & 18.64 & 0.21 & Clay & 2.21 & 1.02 \\
\hline \multicolumn{13}{|c|}{ Profile 9. Native Forest Area 3 (NFA3)—CAMBISSOLO HAPLICO Ta Eutrofico vertissolico (CXve) } \\
\hline$A(0-8)$ & 11.2 & 307 & 202 & 509 & 126 & 365 & 261 & 28.63 & 0.35 & Sandy clay & 2.25 & 0.94 \\
\hline $\mathrm{BA}(8-19)$ & 12.0 & 303 & 179 & 482 & 158 & 360 & 323 & 10.22 & 0.44 & Sandy clay & 2.34 & 1.30 \\
\hline Bi (19-60) & 7.6 & 211 & 140 & 351 & 113 & 536 & 414 & 22.81 & 0.21 & Clay & 2.53 & 1.31 \\
\hline Cv (slinkensides) $(60-200+)$ & 5.9 & 213 & 127 & 340 & 115 & 545 & 432 & 20.78 & 0.21 & Clay & 2.42 & 1.52 \\
\hline \multicolumn{13}{|c|}{ Profile 10. Cajaraneira (Spondia sp.) Orchard Area (COA)—CAMBISSOLO HAPLICO Ta Eutrofico tipico (CXve) } \\
\hline $\mathrm{A}(0-12)$ & 2.2 & 291 & 156 & 447 & 154 & 399 & 345 & 13.47 & 0.39 & Clay loam & 2.32 & 1.17 \\
\hline $\mathrm{AB}(12-24)$ & 2.0 & 334 & 122 & 456 & 77 & 467 & 388 & 16.92 & 0.16 & Sandy clay & 2.33 & 1.17 \\
\hline BA (24-41) & 1.3 & 356 & 67 & 423 & 89 & 488 & 405 & 17.01 & 0.18 & Clay & 2.58 & 1.20 \\
\hline Bi (41-92) & 1.6 & 228 & 123 & 351 & 87 & 562 & 411 & 26.90 & 0.15 & Clay & 2.50 & 1.22 \\
\hline BC (92-115) & 2.0 & 227 & 118 & 345 & 112 & 543 & 371 & 31.70 & 0.21 & Clay & 2.42 & 1.34 \\
\hline
\end{tabular}

Note. $\mathrm{CDW}=$ clay dispersed in water; $\mathrm{DF}=$ degree of flocculation; SiBCS-Brazilian Soil Classification System; $\mathrm{Dp}=$ particle density; $\mathrm{Ds}=$ soil density.

\subsection{Chemical Attributes}

The total organic carbon (TOC) of all profiles decreased with depth (Table 3), however with high and good levels (Ribeiro et al., 1999), denoting their representativeness for semiarid environments (Marinho et al., 2016), especially in the surface of the profiles CNF, and CAP2, which presented 48.42, and $45.52 \mathrm{~g} \mathrm{~kg}-1$, respectively, in the surface layer.

The $\mathrm{pH}$ in water of the Argissolo Vermelho Distrofico latossolico (CCA) was acidic (5.6 to 6.5), confirming its aluminum contents $(0.48$ to $0.58 \mathrm{cmolc} \mathrm{kg}$ ), potential acidity ( 2.31 to $3.74 \mathrm{cmolc} \mathrm{kg}$ ), and, consequently, aluminum saturation ( $15 \%$ to $20 \%$ ). However, it exhibited the lowest cation exchange capacity at $\mathrm{pH} 7.0$ (from 5.17 (Bw Horizon) to 7.31 (A Horizon) $\mathrm{cmolc} \mathrm{kg}^{-1}$ ), and base saturation (41\% to 55\%) and, thus, this soil was classified as dystrophic. This soil presented advanced actions of chemical weathering in the AB and diagnostic Bt horizons $(\mathrm{V}=41 \%)$, which gave it the latossolico character at pedogenesis, despite the low precipitation in the semiarid region, which favors the leaching of basic cations, forming horizons with chemical limitations. However, the $\mathrm{A}$ and $\mathrm{Bw}$ horizons maintained enough $\mathrm{Ca}^{2+}$ and $\mathrm{Na}^{+}$contents to classify them as eutrophic $(\mathrm{V}=$ $50 \%$, and 55\%, respectively). According to Kiehl (1979), $\mathrm{pH}$ lower than 5.0 cause deficiency in the $\mathrm{Ca}^{2+}, \mathrm{Mg}^{2+}$, and $\mathrm{P}$ divalent bases, and toxicity by $\mathrm{Al}^{3+}$ because of its greater solubility in this $\mathrm{pH}$ range, whereas $\mathrm{pH}$ of 8.0 to 8.5 indicate the presence of calcium and magnesium carbonate.

The other soil classes had, in general, alkaline $\mathrm{pH}$ in water, especially the Chernossolo Rendzico (CAP1) (8.0 to 8.3) and Neossolo Fluvico (PPA) (8.0 to 8.1) (Table 3). This high pH values is due to the influence of the sandstones of the Jandaira geological formation, which according to Melo et al. (2017), presents strata with basic rocks rich in carbonates that provide significant $\mathrm{Ca}$ and $\mathrm{Mg}$ contents, increasing base saturation, and classify them as eutrophic, especially the Neossolo, which is in a sediment deposition area. Moreira et al. (2007) evaluated soil chemical and physical attributes in Chapada do Apodi and found effects of the lithology of the region on $\mathrm{pH}$, showing that soils derived from limestones present a neutral to alkaline $\mathrm{pH}$ due to their high carbonate and exchangeable base contents. Similar results were found in the study profiles, denoted by the high $\mathrm{Ca}$ and $\mathrm{Mg}$ contents, with variations in $\mathrm{Ca}$ from 6.63 (Chernossolo; CAP1; Ck3) to $24.07 \mathrm{cmolc}_{\mathrm{kg}^{-1}}$ 
(Cambissolo; NFA1; C), and Mg from 1.35 (Chernossolo; AEA; C) to $13.84 \mathrm{cmolc} \mathrm{kg}^{-1}$ (Cambissolo; NFA1; Bi). Alkalinity is common in semiarid regions due to their low precipitation rates (Souza et al., 2007).

The $\mathrm{pH}$ in $\mathrm{KCl}$ was lower than in water in all profiles, indicating the predominance of negative net charges on the particle surfaces, which is an indicator of the soil weathering stage. The lower the $\Delta \mathrm{pH}$ (more negative), the lower the soil weathering degree; however, negative net charges predominate even in the more weathered soil (Argissolo Vermelho Distrofico latossolico; CCA) $(\Delta \mathrm{pH}$ of -1.5 to -1.8 ) (Table 3$)$ due to the leaching of exchangeable bases, indicating an advanced weathering degree (Melo et al., 2006).

The lowest electric conductivities (EC) were found in the Argissolo Vermelho (CCA), and Neossolo Fluvico (PPA), ranging from $0.03 \mathrm{dS} \mathrm{m}^{-1}$ (Bw Horizon) to $0.09 \mathrm{dS} \mathrm{m}^{-1}$ (A Horizon), and from $0.8 \mathrm{dS} \mathrm{m}^{-1}$ (C Horizon) to 0.11 (A Horizon) $\mathrm{dS} \mathrm{m}^{-1}$, respectively (Table 3). These low EC denote a reduced effect of exchangeable Na and, consequently, lower percentages of exchangeable $\mathrm{Na}(0 \%$ to $1 \%)$, showing no salinity or sodicity for these soils (Santos et al., 2013)

The Chernossolo Rendzico (CAP1) differed from the other soil classes, presenting the highest CE (0.44 to 1.30 $\mathrm{dS} \mathrm{m}^{-1}$ ) and exchangeable sodium percentages (ES \%) (5 to $\left.18 \%\right)$, especially in the A (6\%), and $\mathrm{Ck} 2(18 \%)$ horizons, with exchangeable $\mathrm{Na}^{+}$contents of 0.44 to $2.38 \mathrm{cmolc} \mathrm{kg}^{-1}$ (Table 3). This was due to the groundwater oscillations, indicating a natural tendency of this area for solodicity and sodicity (characterizing the halomorphism pedogenic process), since the critical limits for defining solodic saline soils are ES \% between $6 \%$ and $15 \%, \mathrm{EC}<4 \mathrm{dS} \mathrm{m}^{-1}$, and sodic soils are ES \% above 15\%, and pH usually between 8.5 and 10 (Santos et al., 2013b; Ribeiro et al., 1999).

In general, phosphorus (P) were very low (Table 3), decreasing with depth, especially in the Argissolo Vermelho (CCA), ranging from 0.46 (Bw Horizon) to $7.01 \mathrm{mg} \mathrm{kg}^{-1}$ (A Horizon), and even lower in the more weathered horizons (AB, Bt, and Bw). Chaves et al. (2009) evaluated adsorption characteristics of $\mathrm{P}$ in different soil classes in the state of Paraiba, semiarid region of Brazil, and found similar results, with lower P contents in weathered soils due to the clay content and type, compared to soils that have a predominance of $\mathrm{Fe}$ and $\mathrm{Al}^{+3}$ oxides, which present higher adsorption force on $\mathrm{P}$ due to positive electric charges, strongly binding it to mineral colloids, and decreasing their availability in the soil solution (Machado \& Souza, 2012).

The Cambissolos (NFA1, CNF, AEA, CAP2, NFA2, NFA3, and COA) also presented low P contents due to the low P content on the source material (limestone of the Jandaira formation) (Costa et al., 2016). However, the profile CAP2 (Cambissolo Haplico Ta Eutrofico tipico) presented P contents of $21.03 \mathrm{mg} \mathrm{kg}^{-1}$ in A horizon (0-5 $\mathrm{cm})$ to $9.21 \mathrm{mg} \mathrm{kg}^{-1}$ in the Bi horizon (Ribeiro et al., 1999). This soil presented the second highest TOC content (45.52 $\mathrm{g} \mathrm{kg}^{-1}$ ) on the surface layer due to presence of litterfall, and was shallower than the others. Soil $\mathrm{P}$ availability also depends on organic matter content, and its weathering degree. Less developed soils can be sources of $\mathrm{P}$ because it has natural reserves of primary phosphates from rocks that can be released to the soil (Pavinato \& Rosolem, 2008). This confirms the positive correlation between TOC and $\mathrm{P}$ in the correlation matrix of physical and chemical attributes of the soil profiles (Table 5).

Table 3. Chemical attributes of representative soil profiles of the Terra da Esperança Settlement Project, in Governor Dix-Sept Rosado, RN, Brazil

\begin{tabular}{|c|c|c|c|c|c|c|c|c|c|c|c|c|c|c|c|c|c|c|c|}
\hline Horizon/Profile & $\mathrm{CaCO}_{3}$ & TOC & $\mathrm{pH}($ & $1: 2.5)$ & $\Delta \mathrm{pH}$ & $\mathrm{EC}$ & $\mathrm{P}$ & $\mathrm{K}^{+}$ & $\mathrm{Na}^{+}$ & $\mathrm{Ca}^{2+}$ & $\mathrm{Mg}^{2+}$ & $\mathrm{Al}^{3+}$ & $(\mathrm{H}+\mathrm{Al})$ & SB & $\mathrm{t}$ & $\mathrm{T}$ & $\begin{array}{l}\text { Clay } \\
\text { Activity }\end{array}$ & $\mathrm{V}$ & $\mathrm{ES} \%$ \\
\hline ------------ cm -----------. & $---\mathrm{g} \mathrm{kg}$ & $\mathrm{g}^{-1}---$ & $\mathrm{H}_{2} \mathrm{O}$ & $\mathrm{KCl}$ & & $\mathrm{dS} \mathrm{m}$ & $\mathrm{mg} \mathrm{kg}^{-1}$ & ----- & ----- & -------- & ------- & & cmolc $\mathrm{k}$ & $\mathrm{rg}^{-1}-$ & - & -------- & --------- & ----- 0 & ----- \\
\hline \multicolumn{20}{|c|}{ Profile 1. Native Forest Area 1 (NFA1)_CAMBISSOLO HAPLICO Carbonatico vertissolico (CXk) } \\
\hline A moderate $(0-8)$ & 0 & 27.90 & 7.4 & 6.0 & -1.4 & 0.36 & 4.42 & 0.05 & 0.09 & 21.70 & 3.06 & 0 & 0 & 24.90 & 24.90 & 24.90 & 69.08 & 1000 & 0 \\
\hline $\mathrm{Bi}(8-37)$ & 0 & 8.23 & 7.5 & 5.6 & -1.8 & 0.36 & 2.33 & 0.13 & 0.16 & 19.83 & 13.84 & 0 & 0 & 33.96 & 33.96 & 33.96 & 75.00 & 1000 & 0 \\
\hline $\mathrm{C}(37-52)$ & 243.69 & 5.67 & 7.6 & 7.0 & -0.6 & 0.35 & 2.86 & 0.04 & 0.06 & 24.07 & 2.96 & 0 & 0 & 27.13 & 27.13 & 27.13 & 107.67 & 1000 & 0 \\
\hline \multicolumn{20}{|l|}{$\mathrm{R}(52+)$} \\
\hline \multicolumn{20}{|c|}{ Profile 2. Collective Area with Native Forest (CNF)_CAMBISSOLO HAPLICO Carbonatico tipico (CXk) } \\
\hline A weak (0-3) & 49.55 & 48.42 & 7.7 & 7.2 & -0.5 & 0.37 & 6.88 & 0.05 & 0.04 & 15.63 & 3.26 & 0 & 0 & 18.98 & 18.98 & 18.98 & 75.91 & 1000 & 0 \\
\hline $\mathrm{AB}(3-7)$ & 58.35 & 39.34 & 7.8 & 7.3 & -0.6 & 0.22 & 7.17 & 0.36 & 0.03 & 14.27 & 2.92 & 0 & 0 & 17.58 & 17.58 & 17.58 & 66.47 & 1000 & 0 \\
\hline $\mathrm{Bi}(7-22)$ & 114.87 & 10.98 & 7.7 & 7.2 & -0.5 & 0.16 & 1.12 & 0.18 & 0.07 & 13.87 & 1.80 & 0 & 0 & 15.91 & 15.91 & 15.91 & 46.20 & 1000 & 0 \\
\hline $\mathrm{BiC}(22-36)$ & 125.90 & 8.03 & 8.1 & 7.3 & -0.8 & 0.19 & 1.87 & 0.11 & 0.07 & 13.30 & 1.78 & 0 & 0 & 15.27 & 15.27 & 15.27 & 46.07 & 1000 & 0 \\
\hline CB (36-52) & 164.87 & 8.01 & 8.1 & 7.3 & -0.8 & 0.18 & 0.37 & 0.08 & 0.08 & 12.87 & 1.62 & 0 & 0 & 14.65 & 14.65 & 14.65 & 43.86 & 1000 & 1 \\
\hline $\mathrm{C}$ fragmented (52-145) & 603.49 & 2.96 & 8.2 & 7.4 & -0.8 & 0.19 & 2.39 & 0.07 & 0.08 & 10.17 & 1.61 & 0 & 0 & 11.92 & 11.92 & 11.92 & 59.60 & 1000 & 1 \\
\hline $\mathrm{R}(145+)$ & & & & & & & & & & & & & & & & & & & \\
\hline
\end{tabular}


Profile 3. Agroecological Area (AEA)—CAMBISSOLO Haplico Carbonatico tipico (CXk)

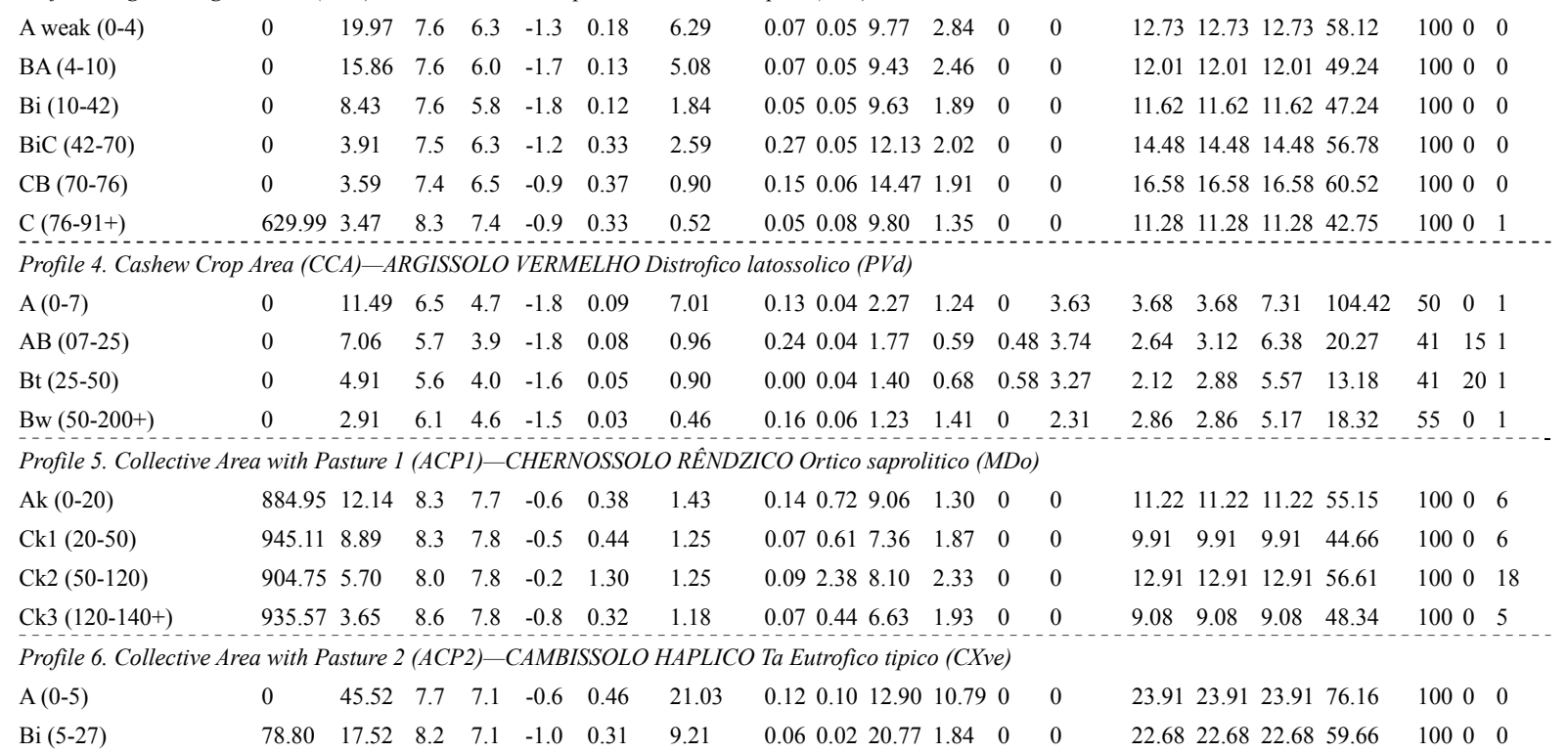

CR (27+)

Profile 7. Native Forest Area 2 (NFA2)-CAMBISSOLO HAPLICO Ta Eutrofico tipico (CXve)

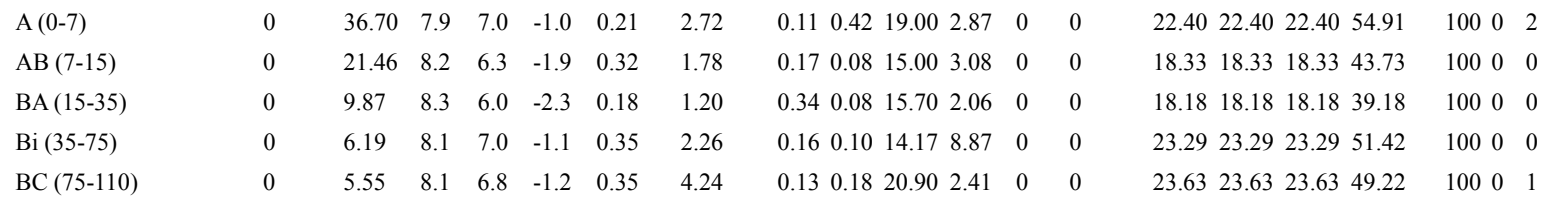

$\mathrm{R}(110+)$

Profile 8. Permanent Preservation Area (PPA)-NEOSSOLO FLÚVICO Ta Eutrofico tipico (RYve)

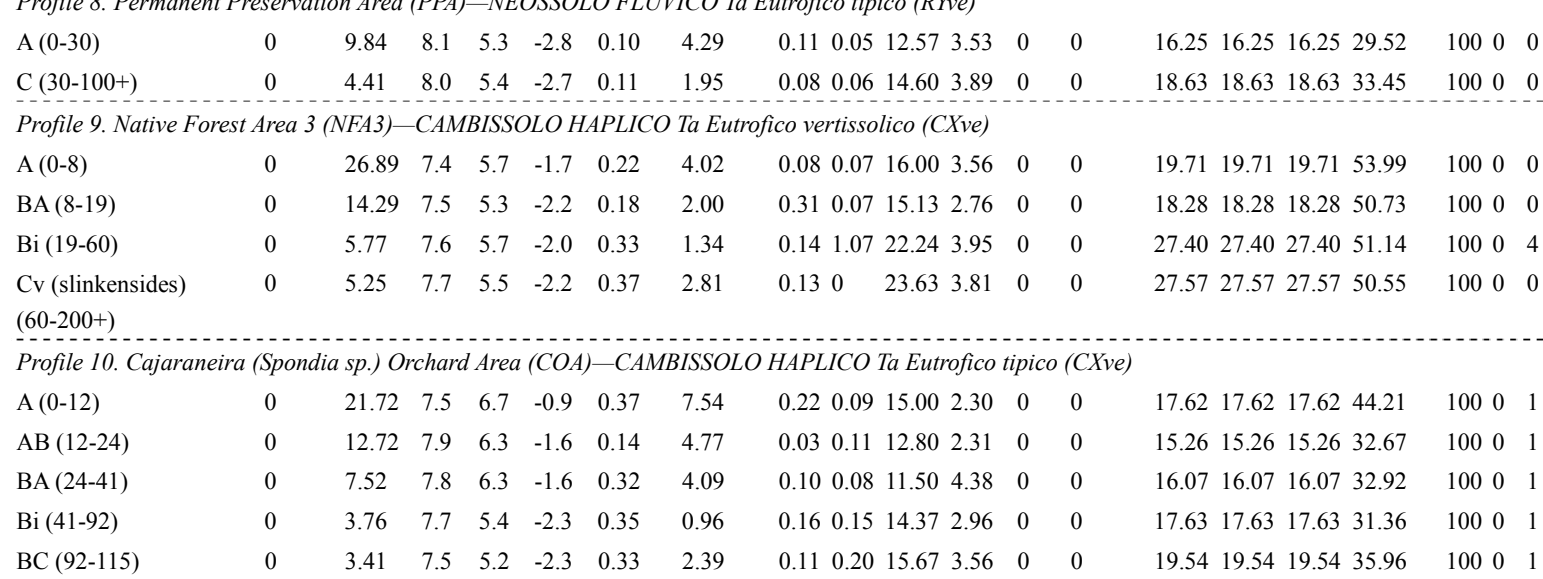

R (115+)

Note. $\mathrm{TOC}=$ Total organic carbon; $\mathrm{EC}=$ Electrical conductivity of soil saturation extract; $\mathrm{SB}=$ sum of bases; $\mathrm{t}=$ Effective cation exchange capacity; $\mathrm{T}=$ cation exchange capacity at $\mathrm{pH} 7.0 ; \mathrm{V}=$ Base Saturation; $\mathrm{m}=$ Aluminum saturation; ES\% = Exchangeable Sodium Percentage.

The soil potassium $\left(\mathrm{K}^{+}\right)$contents ranged from 0.00 (Argissolo Vermelho; CCA; Bt Horizon) to $0.36 \mathrm{cmolc} \mathrm{kg}^{-1}$ (Cambissolo Haplico; CNF; AB Horizon) (Table 3). The $\mathrm{K}^{+}$contents in the subsurface of the Cambissolo Haplico (CNF) denoted the leaching of this ion from the 0-12 cm layer (A Horizon) to the deeper layers, increasing its content because $\mathrm{K}^{+}$is a monovalent ion that produces weaker bindings than bivalent ions (e.g. magnesium), favoring its moving to deeper horizons (Melo et al., 2008).

\subsection{Soil Class Mapping of the Terra de Esperança Settlement Project (TESP)}

The Soil Exploration-Reconnaissance Survey of the state of Rio Grande do Norte (Jacomine et al., 1971) reported that the region of the TESP in Governador Dix-Sept Rosado had only Cambissolos. However, three 
other soil classes were found: Argissolo Vermelho Distrofico latossolico, Chernossolo Rendzico Ortico saprolitico, and Neossolo Fluvico Ta Eutrofico tipico (Figure 2).

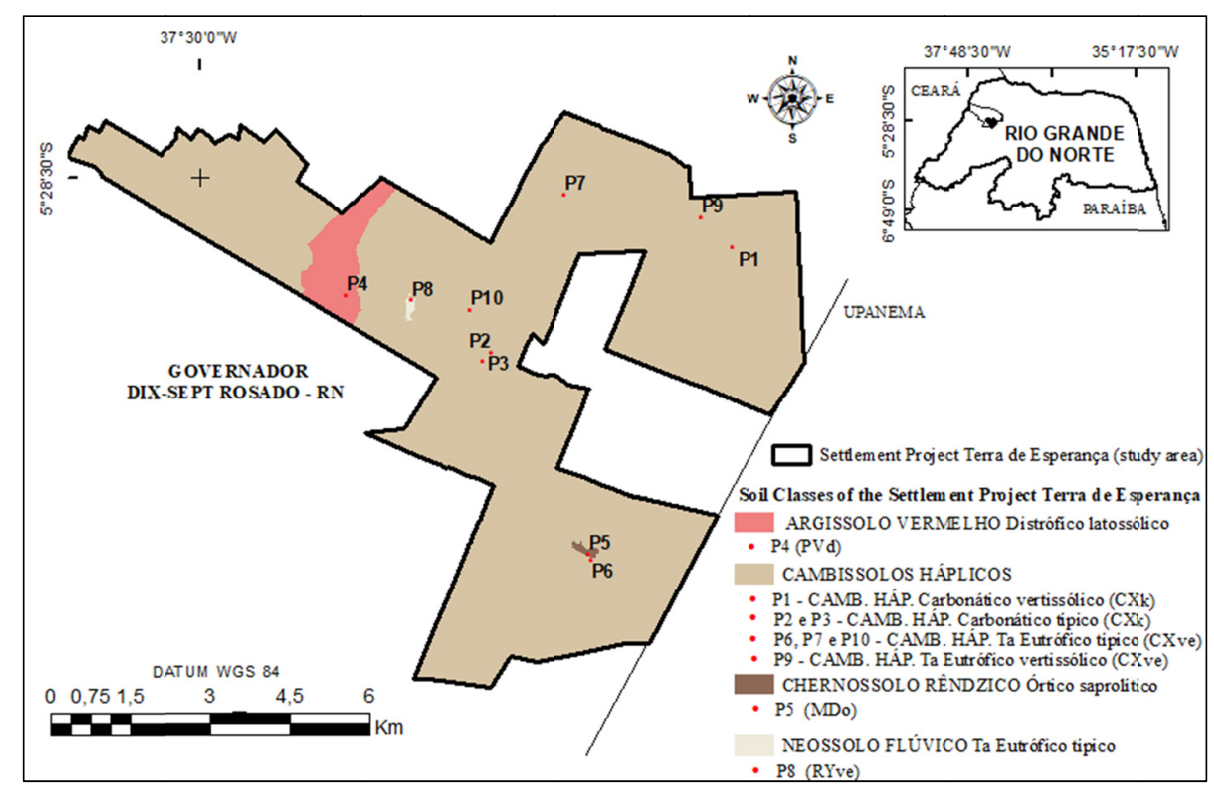

Figure 2. Soil classes of the Terra de Esperança Settlement Project, Governor Dix-Sept Rosado, RN, Brazil, according to the SiBCS (Santos et al., 2013)

According to the area of each soil class found, the Cambissolos Haplicos occupy the greater part of the TESP $(96.50 \%)$ (Table 4). In general, Cambissolos have flat relief with little alteration of the source material, forming shallow to deep soils, with good nutrient reserves and water storage capacity, good agricultural potential, and can be used for annual and perennial crop cycles, pastures, and reforestation. However, this soil may present limitations, such as risk of erosion, rockiness, and depths lower than $50 \mathrm{~cm}$, which can affect the performance of agricultural implements when it has a vertissolico character (Jarbas et al., 2018).

Table 4. Percentage of area of each soil class in the Terra de Esperança Settlement Project, Governor Dix-Sept Rosado, RN, Brazil

\begin{tabular}{lll}
\hline Class of soils & Area (ha) & Percentage of area (\%) \\
\hline Cambissolo Háplico & 6076.50 & 96.50 \\
Argissolo Vermelho & 207.60 & 3.30 \\
Chernossolo Rêndzico & 7.20 & 0.11 \\
Neossolo Flúvico & 5.70 & 0.09 \\
\hline TOTAL & 6297 & 100 \\
\hline
\end{tabular}

\subsection{Statistical Analysis}

The correlation matrix between the soil attributes showed the silt fraction with a high and positive correlation with $\mathrm{CaCO}_{3}$, and $\mathrm{ES} \%$ (Table 5). The clay fraction was mainly correlated with $\Delta \mathrm{pH}$, and cation exchange capacity at $\mathrm{pH} 7.0(\mathrm{~T}) . \mathrm{CaCO}_{3}$ presented correlation with $\mathrm{pH}_{2} \mathrm{O}, \mathrm{pH} \mathrm{KCl}, \Delta \mathrm{pH}, \mathrm{EC}, \mathrm{Na}^{+}, \mathrm{Ca}^{2+}, \mathrm{T}$, and $\mathrm{ES} \%$, denoting the influence of the source material on many soil attributes. The $\mathrm{pH}$ in water had high and significant correlation with aluminum $\left(\mathrm{Al}^{3+}\right)$, potential acidity $(\mathrm{H}+\mathrm{Al})$, base saturation $(\mathrm{V})$, aluminum saturation $(\mathrm{m})$, and calcium. Sodium presented correlations with sand, silt, $\mathrm{CaCO}_{3}, \mathrm{EC}$, and $\mathrm{ES} \%$. 
Table 5. Correlation matrix between the physical and chemical attributes of the soil profiles in the Terra de Esperança Settlement Project, Governor Dix-Sept Rosado, RN, Brazil

\begin{tabular}{|c|c|c|c|c|c|c|c|c|c|c|c|c|c|c|c|c|c|c|c|c|}
\hline Attributes & Sand & Silt & Clay & $\mathrm{CaCO}_{3}$ & TOC & $\mathrm{pH}_{\mathrm{H} 2 \mathrm{O}}$ & $\mathrm{pH} \mathrm{KCl}$ & $\Delta \mathrm{pH}$ & $\mathrm{CE}$ & $P$ & $\mathrm{~K}^{+}$ & $\mathrm{Na}^{+}$ & $\mathrm{Ca}^{2+}$ & $\mathrm{Mg}^{2+}$ & $\mathrm{Al}^{3+}$ & $(\mathrm{H}+\mathrm{Al})$ & $\mathrm{T}$ & V & $\mathrm{m}$ & ES\% \\
\hline Sand & 1.00 & & & & & & & & & & & & & & & & & & & \\
\hline Silt & -0.67 & 1.00 & & & & & & & & & & & & & & & & & & \\
\hline Clay & -0.40 & -0.42 & 1.00 & & & & & & & & & & & & & & & & & \\
\hline $\mathrm{CaCO}_{3}$ & -0.49 & 0.88 & -0.49 & 1.00 & & & & & & & & & & & & & & & & \\
\hline TOC & 0.29 & -0.17 & -0.15 & -0.23 & 1.00 & & & & & & & & & & & & & & & \\
\hline $\mathrm{pH}_{\mathrm{H} 2 \mathrm{O}}$ & -0.52 & 0.45 & 0.09 & 0.42 & 0.05 & 1.00 & & & & & & & & & & & & & & \\
\hline $\mathrm{pH}_{\mathrm{KCl}}$ & -0.31 & 0.59 & -0.36 & 0.61 & 0.23 & 0.77 & 1.00 & & & & & & & & & & & & & \\
\hline$\Delta \mathrm{pH}$ & 0.03 & 0.48 & -0.63 & 0.53 & 0.29 & 0.22 & 0.79 & 1.00 & & & & & & & & & & & & \\
\hline $\mathrm{CE}$ & -0.45 & 0.52 & -0.09 & 0.49 & 0.03 & 0.33 & 0.49 & 0.44 & 1.00 & & & & & & & & & & & \\
\hline$P$ & 0.30 & -0.21 & -0.10 & -0.25 & 0.68 & 0.02 & 0.14 & 0.19 & 0.07 & 1.00 & & & & & & & & & & \\
\hline $\mathrm{K}^{+}$ & 0.02 & -0.09 & 0.08 & -0.23 & 0.07 & -0.03 & -0.11 & -0.14 & -0.06 & -0.02 & 1.00 & & & & & & & & & \\
\hline $\mathrm{Na}^{+}$ & -0.51 & 0.60 & -0.12 & 0.58 & -0.13 & 0.20 & 0.32 & 0.29 & 0.80 & -0.18 & -0.08 & 1.00 & & & & & & & & \\
\hline $\mathrm{Ca}^{2+}$ & -0.19 & -0.22 & 0.50 & -0.30 & 0.21 & 0.44 & 0.23 & -0.07 & 0.18 & 0.13 & 0.04 & -0.07 & 1.00 & & & & & & & \\
\hline $\mathrm{Mg}^{2+}$ & -0.10 & -0.15 & 0.31 & -0.24 & 0.23 & 0.12 & 0.01 & -0.09 & 0.19 & 0.40 & 0.02 & -0.04 & 0.36 & 1.00 & & & & & & \\
\hline $\mathrm{Al}^{3+}$ & 0.16 & -0.19 & 0.04 & -0.11 & -0.14 & -0.70 & -0.52 & -0.12 & -0.25 & -0.16 & -0.05 & -0.09 & -0.46 & -0.22 & 1.00 & & & & & \\
\hline$(\mathrm{H}+\mathrm{Al})$ & 0.45 & -0.26 & -0.23 & -0.16 & -0.16 & -0.86 & -0.65 & -0.17 & -0.35 & -0.08 & 0.03 & -0.13 & -0.65 & -0.27 & 0.73 & 1.00 & & & & \\
\hline $\mathrm{T}$ & -0.17 & -0.26 & 0.53 & -0.35 & 0.25 & 0.31 & 0.12 & -0.11 & 0.23 & 0.25 & 0.06 & -0.04 & 0.93 & 0.66 & -0.39 & -0.54 & 1.00 & & & \\
\hline V & -0.42 & 0.26 & 0.20 & 0.16 & 0.18 & 0.88 & 0.66 & 0.17 & 0.36 & 0.11 & -0.01 & 0.13 & 0.66 & 0.28 & -0.76 & -0.99 & 0.55 & 1.00 & & \\
\hline $\mathrm{m}$ & 0.16 & -0.19 & 0.04 & -0.11 & -0.14 & -0.70 & -0.52 & -0.12 & -0.25 & -0.16 & -0.07 & -0.09 & -0.46 & -0.22 & 1.00 & 0.73 & -0.38 & -0.76 & 1.00 & \\
\hline ES \% & -0.52 & 0.72 & -0.25 & 0.70 & -0.16 & 0.20 & 0.36 & 0.36 & 0.80 & -0.20 & -0.10 & 0.96 & -0.23 & -0.11 & -0.05 & -0.07 & -0.20 & 0.07 & -0.05 & 1.00 \\
\hline
\end{tabular}

Note. $\mathrm{CaCO}_{3}=$ Calcium Carbonate Equivalent; $\mathrm{TOC}=$ Total Organic Carbon; $\mathrm{EC}=$ electrical conductivity; $\mathrm{H}+\mathrm{Al}=$ potential acidity; $\mathrm{T}=$ cation exchange capacity at $\mathrm{pH} 7.0 ; \mathrm{V}=$ base saturation; $\mathrm{m}=$ saturation by aluminum; ES \% = exchangeable sodium percentage.

The principal component analysis (PCA) and factorial analysis were performed using a data matrix with 18 soil attributes. Delta $\mathrm{pH}(\Delta \mathrm{pH})$, and aluminum saturation $(\mathrm{m})$ were necessary due to their multicollinearity in the correlation matrix.

The principal components analysis generated vector projection diagrams for physical and chemical attributes of the soils for Factors 1 and 2 (Figure 3), and 3 and 4 (Figure 4), which had greater weights in the classification of soil attributes, and allowed confirming their influences for the distinction of the soil classes.

Figure 3a shows the predominance of physical attributes that discriminate the most environments, especially silt and clay, since they are not close in the correlation circle, since and the studied soils presented varied texture classes.

The distribution of the selected variables presented accumulated variance of $57.71 \%$ for the Factor 1 and Factor 2 axes, explaining $32.83 \%$ and $24.88 \%$ of the variance, respectively, forming three groups (Figure 3). 

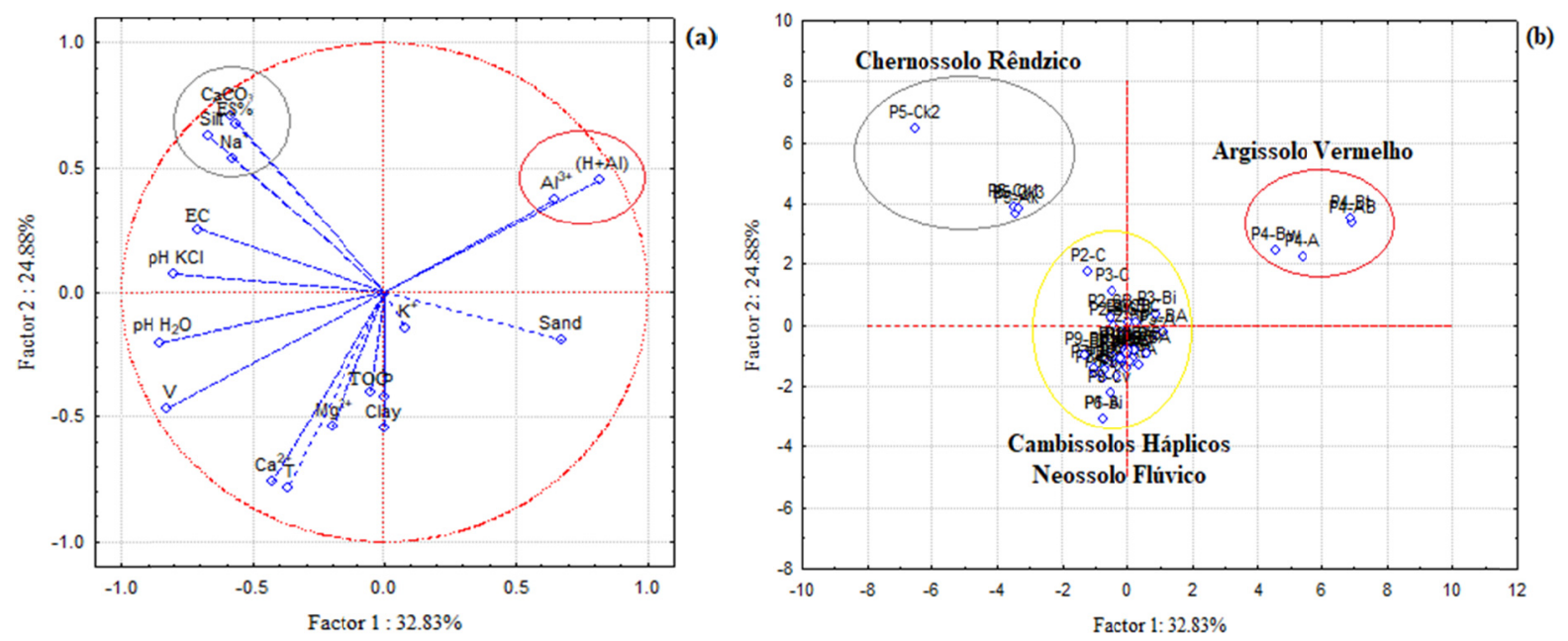

Figure 3. Distribution of the variables in the circle of correlations (a) and distribution of the cloud of points representing the correlation between Factors 1 and 2 (b)

Group 1 was formed by the Argissolo Vermelho $(\mathrm{CCA})$; potential acidity $(\mathrm{H}+\mathrm{Al})$ and aluminum $\left(\mathrm{Al}^{3+}\right)$ were the most discriminant variables for Factor 1, denoting a more acidic, weathered soil when compared to the other soil classes studied. These results are explained by its low silt to clay ratio, low clay activity in depth, and high altitude (97 m) (Table 1).

Group 2 was formed by the Chernossolo Rendzico (CAP1), discriminated by the attributes in Factor 2 silt, calcium carbonate equivalent $\left(\mathrm{CaCO}_{3}\right)$, exchangeable sodium percentage (ES \%), and sodium $\left(\mathrm{Na}^{+}\right)$. This soil is characterized by low development; it is the youngest of the soils evaluated and is more influenced by the source material (Jandaira limestone) and groundwater oscillations, which contributed to risks of soil solodicity and sodicity.

Group 3 was formed by the Cambissolos Haplicos, and Neossolo Fluvico (Figure 3b), due to their similar physical and chemical characteristics; these soils are superimposed in the unitary center, and it is not possible to discriminate them by Factors 1 and 2 .

Factors 3 and 4 showed the distribution of the selected variables with accumulated variance of $20.97 \%$, explaining $11.59 \%$ and $9.38 \%$ of this variance, respectively (Figure 4). Two groups were formed represented by the Cambissolos Haplicos (CAP2, NFA3, and COA), and the Neossolo Fluvico (PPA), discriminated mainly by the TOC, and P (CAP2; surface horizon), and clay fraction (PPA; A, and C), NFA3 (Cv), COA (Bi, and BC), because they present the highest results for these attributes. The Neossolo Fluvico (PPA) was in this group due to its position, in the lowest part of the landscape with altitude of $74 \mathrm{~m}$, characterized by outcropping and accumulation of water in rainy periods due to groundwater oscillations, andsediment deposition, which favors the predominance of the clay fraction (Table 2), resulting in good chemical characteristics.

The PCA showed clear distinctions between the environments and the most sensitive attributes for their distinction. According to Santos et al. (2015), chemical attributes - organic carbon content, active acidity, potential acidity, sum of bases, and base saturation-were determinants for the discrimination of profiles of Cambissolos Humicos, and pore distribution and volume, soil density, and total porosity were determinant for discrimination of soil profiles. Freitas et al. (2014) evaluated chemical attributes a Latossolo Vermelho distrofico under different managements and found that the main attributes for distinguishing the environments were calcium for an area of sugarcane, potential acidity for an area of forest, and manganese and copper for a reforested area. 

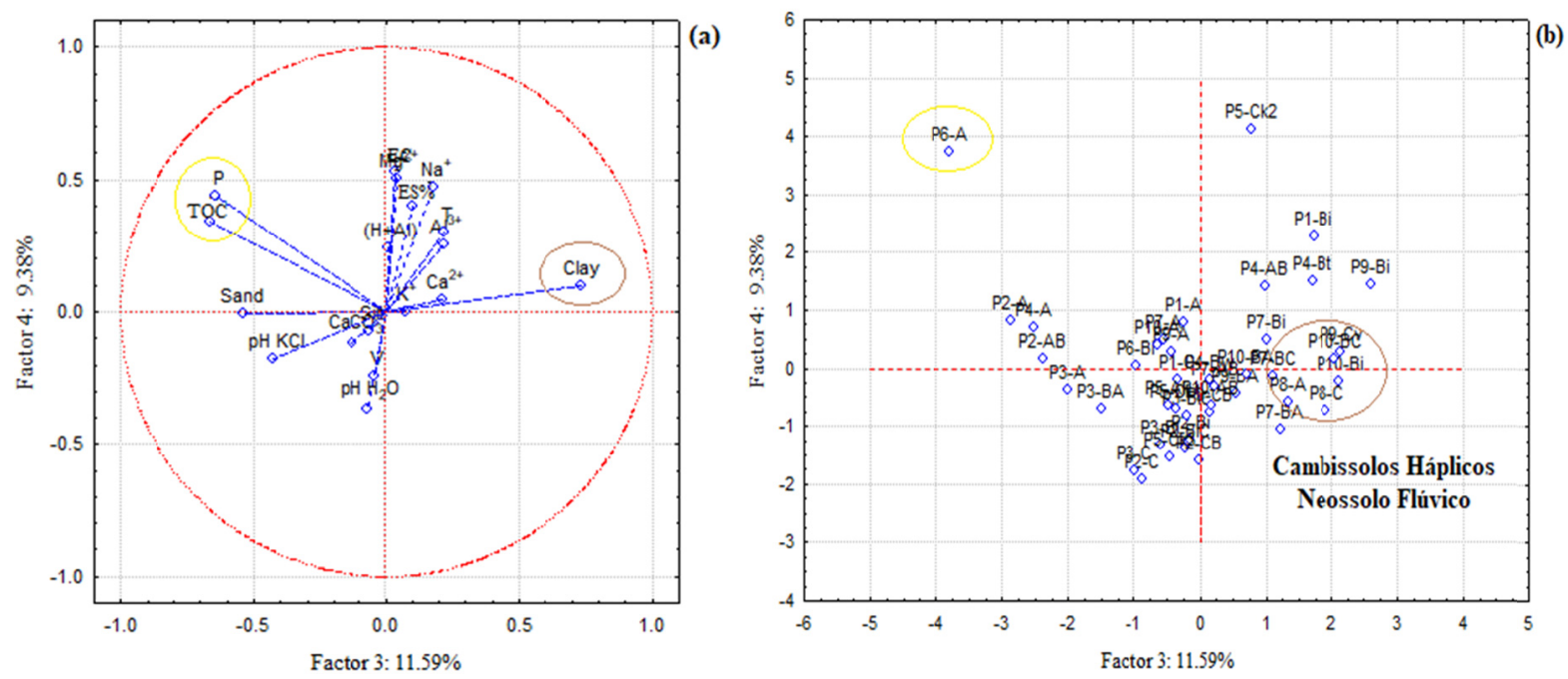

Figure 4. Distribution of variables in the circle of correlations (a) and distribution of the cloud of points representing the relationship between Factors 3 and 4 (b)

Table 6 shows the factorial loads of physical and chemical attributes of the soil profiles and their respective eigenvalues, and total and accumulated variances. Factors 1, 2, 3, and 4 were selected because they met the criterion of eigenvalues greater than 1 . These four factors together accounted for $78.68 \%$ of the total variance of the data.

Factor 1 had greater influence on the differentiation of the profiles, with $32.83 \%$ of the total variance of the data, which was related to the soil acidity, composed in order of importance by the variables: $\mathrm{pH} \mathrm{H}_{2} \mathrm{O},(\mathrm{H}+\mathrm{Al}), \mathrm{V}, \mathrm{Al}^{3+}$, and $\mathrm{pH} \mathrm{KCl} \mathrm{(Table} \mathrm{6).} \mathrm{The} \mathrm{main} \mathrm{indicators} \mathrm{of} \mathrm{soil} \mathrm{acidity} \mathrm{used} \mathrm{in} \mathrm{Brazil} \mathrm{are} \mathrm{pH}$ in water, base saturation, and exchangeable aluminum and hydrogen (Sousa \& Lobato, 2004; Nicolodi et al., 2008). The pH varied from acid in the Argissolo Vermelho (CCA) to alkaline in the Chernossolo Rendzico (CAP1), Cambissolos Haplicos (NFA1, CNF, AEA, CAP2, NFA2, NFA3, and COA) and Neossolo Fluvico (PPA) (from highest to lowest), thus contributing to the water route and the weathering intensity, showing a great variation of soil classes in a small area.

Factor 2 explained $24.88 \%$ of the total variance of the data (Table 6 ), represented by $\mathrm{ES} \%, \mathrm{Na}^{+}$basic cation, $\mathrm{EC}$, silt fraction, and $\mathrm{CaCO}_{3}$, which are related to soil salinity. The simplest evaluation of soil salinity is based on EC, $\mathrm{ES} \%$, and $\mathrm{pH}$. The soil EC shows the effect of salinity on plants, and ES \% shows the effect of $\mathrm{Na}$ on soil properties (Ribeiro et al., 2010; Queiroz et al., 2010). Chernossolo Rendzico Ortico saprolitico (Table 3) was the only soil that presented risks of sodicity in surface layers and sodicity in deeper layers (Table 3), and it had the highest silt content (Table 2) due to the influence of the groundwater oscillations that favors the accumulation of salts, and the source material. 
Table 6. Matrix of factorial loads after orthogonal rotation by the Varimax method for physical and chemical attributes of soil profiles in the Terra de Esperança Settlement Project, Governor Dix-Sept Rosado, RN, Brazil

\begin{tabular}{|c|c|c|c|c|}
\hline \multirow{3}{*}{ Attributes } & \multicolumn{4}{|c|}{ Factorial loads (1) } \\
\hline & Factor 1 & Factor 2 & Factor 3 & Factor 4 \\
\hline & Soil acidity & Soil salinity & Nutrient availability & Clay activity \\
\hline Sand & -0.36 & 0.59 & 0.49 & -0.23 \\
\hline Silt & 0.34 & -0.70 & -0.21 & -0.45 \\
\hline Clay & 0.02 & 0.14 & -0.35 & 0.84 \\
\hline $\mathrm{CaCO}_{3}$ & 0.28 & -0.66 & -0.20 & -0.56 \\
\hline TOC & 0.14 & 0.09 & 0.83 & 0.04 \\
\hline $\mathrm{pH} \mathrm{H} \mathrm{H}_{2} \mathrm{O}$ & 0.93 & -0.20 & -0.09 & 0.00 \\
\hline $\mathrm{pH} \mathrm{KCl}$ & 0.76 & -0.37 & 0.21 & -0.32 \\
\hline $\mathrm{EC}$ & 0.22 & -0.87 & 0.16 & 0.13 \\
\hline $\mathrm{P}$ & 0.06 & 0.07 & 0.87 & 0.11 \\
\hline $\mathrm{K}^{+}$ & -0.03 & 0.12 & -0.01 & 0.14 \\
\hline $\mathrm{Na}^{+}$ & 0.01 & -0.93 & -0.08 & -0.01 \\
\hline $\mathrm{Ca}^{2+}$ & 0.56 & 0.10 & 0.10 & 0.69 \\
\hline $\mathrm{Mg}^{2+}$ & 0.12 & -0.12 & 0.40 & 0.63 \\
\hline $\mathrm{Al}^{3+}$ & -0.80 & 0.02 & -0.14 & -0.06 \\
\hline$(\mathrm{H}+\mathrm{Al})$ & -0.92 & 0.12 & -0.01 & -0.26 \\
\hline $\mathrm{T}$ & 0.40 & 0.00 & 0.23 & 0.82 \\
\hline $\mathrm{V}$ & 0.94 & -0.11 & 0.04 & 0.24 \\
\hline ES \% & 0.00 & -0.95 & -0.10 & -0.19 \\
\hline Eigenvalues & 5.91 & $4.48^{--}$ & 2.09 & 1.69 \\
\hline Total variance $(\%)$ & 32.83 & 24.88 & 11.59 & 9.38 \\
\hline Accumulated variance $(\%)$ & 32.83 & 57.71 & 69.30 & 78.68 \\
\hline
\end{tabular}

Note. (1) For the purpose of interpretation, factorial loads $\geq 0.65$ were significant.

Factor 3 (soil nutrient availability) was composed of TOC, and P, and Factor 4 by clay activity, clay, T, and $\mathrm{Ca}^{2+}$. These factors explained $11.59 \%$, and $9.38 \%$ of the total variance of the data, respectively (Table 6 ). The soil organic matter is important for the supplying of nutrients to plants, especially phosphorus, which is a limiting nutrient for the development of plants (Pavinato \& Rosolem, 2008).

$\mathrm{K}^{+}$presented the lowest and similar factorial loads (Table 6), thus, it was not significant in any of the factors.

\section{Conclusions}

The soil classes found in the Terra de Esperança Settlement Project, in Governor Dix-Sept Rosado, Chapada do Apodi, state of Rio Grande do Norte, Brazil, according to the Brazilian Soil Classification System (SiBCS), are: Cambissolo Haplico Carbonatico vertissolico (Native Forest Area 1-NFA), Cambissolo Haplico Carbonatico tipico (Collective Area with Native Forest-CNF, and Agroecological Area-AEA), Cambissolo Haplico Ta Eutrofico tipico (Collective Area with Pasture 2-CAP2, Native Forest Area 2-NFA2, and Cajaraneira (Spondia Al3Argissolo Vermelho Distrofico latossolico (Cashew Crop Area-CCA), Chernossolo Rendzico Ortico saprolitico (Collective Area with Pasture 1-CAP1), and Neossolo Fluvico Ta Eutrofico tipico (Permanent Preservation Area-PPA).

The evolution of the soils under the climatic conditions of the Chapada do Apodi generated sufficient accumulation of $\mathrm{CaCO}_{3}$ to show a calcic horizon in the Cambissolos Haplicos (NFA1, CNF, AEA, and CCA), and Chernossolo Rendzico (CAP1), whose material of origin are carbonaceous rocks.

The sand fraction in the A horizon, clay fraction in the Bt horizon, potential acidity, and aluminum discriminated the Argissolo Vermelho (CCA). Silt, calcium carbonate equivalent, and percentages of exchangeable sodium and sodium discriminated the Chernossolo Rendzico (CAP1). Clay, total organic carbon, and available phosphorus discriminated the Cambissolos Haplicos (CAP2, PPA, NFA3, and COA) and the Neossolo Fluvico (P8). 
The most sensitive attributes for the differentiation of the soil classes were related to the source material, which directly influenced the soil physical (silt and clay), and chemical (acidity, salinity, nutrient availability, and clay activity) attributes.

\section{References}

Alvares, C. A., Stape, J. L., Sentelhas, P. C., Gonçalves, J. L. M., \& Sparovek, G. (2013). Köppen’s climate classification map for Brazil. Meteorologische Zeitschrift, 404(22), 711-728. https://doi.org/10.1127/ 0941-2948/2013/0507

Brady, N. C., \& Weil, R. R. (2013). Elementos da Natureza e Propriedades dos Solos (3rd ed.). Porto Alegre: Bookman.

Chaves, L. H. G., Chaves, I., Nascimento, A., \& Sousa, A. E. C. (2009). Características de adsorção de fósforo em Argissolos, Plintossolos e Cambissolos do Estado da Paraíba. Engenharia Ambiental: Pesquisa e Tecnologia, 6(2).

Costa, M. C. G. (2011). Profundidade do solo e micro-relevo em bananais irrigados: Impactos na nutrição mineral e potencial produtivo. Revista Ciência Agronômica, 42(3), 567-578. https://oi.org/10.1590/ S1806-66902011000300001

Costa, M. C. G., Miotti, A. A., Ferreira, T. O., \& Romero, R. E. (2016). Teor de nutrientes e viabilidade da bananicultura em Cambissolos com diferentes profundidades Bragantia. Campinas, 75(3), 335-343.

DNOCS. (1978). Plano diretor para o aproveitamento dos recursos de solo e água do Vale do Apodi-Rio Grande do Norte. São Paulo, Hidroservice/Ministério do Interior/DNOCS.

Ernesto Sobrinho, F. (1980). Caracterização, gênese e interpretação para uso de solos derivados de calcário da região da Chapada do Apodi, Rio Grande do Norte (Dissertação, Mestrado em Solos e Nutrição de Plantas, Universidade Federal de Viçosa, Viçosa, MG).

Freitas, L. F., Casagrande, J. C., Oliveira, I. A. O., Souza Júnior, P. R., \& Campos, M. C. C. C. (2014). Análises multivariadas de atributos químicos do solo para caracterização de ambientes. Revista Agro@mbiente On-line, 8(2), 155-164. https://doi.org/10.18227/1982-8470ragro.v8i2.1684

Jacomine, P. K. T., Silva, F. B. R., Formiga, R. A., Almeida, J. C., Beltrão, V. A., Pessoa, S. C. P., \& Ferreira, R. C. (1971). Levantamento exploratório-Reconhecimento de solos do Estado do Rio Grande do Norte. Recife, DPP/DA.

Jarbas, T., Sá, I. B., Petrere, V. G., \& Taura, T. A. (2018). Agência Embrapa de Informação Tecnológica: Árvore Do Conhecimento. Bioma Caatinga. Cambissolos.

Kiehl, E. J. (1979). Manual de Edafologia: relação solo-planta (p. 262). Piracicaba: Ceres.

Machado, V. J. S., \& Souza, C. H. E. (2012). Disponibilidade de fósforo em solos com diferentes texturas após aplicação de doses crescentes de fosfato monoamônico de liberação lenta. Bioscience Journal, 28(1).

Maia, R. P. (2005). Planície fluvial do baixo jaguaribe: Evolução geomorfológica, ocupação e análise ambiental Mercator. Revista de Geografia da UFC, 4(8).

Marinho, A. C. C. S., Portela, J. C., Silva, E. F., Dias, N. S., Sousa Junior, F. S., Silva, A. C., \& Silva, J. F. (2016) Organic matter and physicochemical attributes of a cambisol under different agricultural uses in a semi-arid region of Brazil. Australian Journal of Crop Science, 10, 32-41.

Melo, A. F. D., Souza, C. M. M., Rego, L. G. S., Lima, R. N. S., \& Moura, I. N. B. M. (2017). Pedogênese de Chernossolos derivados de diferentes materiais de origem no Rio Grande do Norte, Brasil. Agropecuária Científica no Semiárido, 13(3), 229-235.

Melo, R. M., Barros, M. F. C., Santos, P. M., \& Rolim, M. M. (2008). Correção dos solos salino-sódicos pela aplicação de gesso mineral. Revista Brasileira de Engenharia Agrícola e Ambiental, Campina Grande, 12, 376-380. https://doi.org/10.1590/S1415-43662008000400007

Melo, V. F., Schaefer, C. E. G. R., Fontes, L. E. F., Chagas, A. C., Lemos Júnior, J. B., \& Andrade, R. P. (2006). Caracterização física, química e mineralógica de solos da Colônia Agrícola do Apiaú (Roraima, Amazônia) sob diferentes usos e após queima. R. Bras. Ci. Solo, 30, 1039-1050. https://doi.org/10.1590/S010006832006000600013

Moreira, J. N., Morais, C, E. R., Maia, C. E., \& Gurgel F. J. (2007). Caracterização química e física dos solos do assentamento de reforma agrária MAISA em Mossoró, RN. Revista de Biologia e Ciências da Terra, 7(2). 
Mota, J. C. A., Assis Júnior, R. N., Amaro Filho, J., Romero, R. E., Mota, F. O. B., \& Libardi, P. L. (2007). Atributos mineralógicos de três solos explorados com a cultura do melão na Chapada do Apodi-RN. Revista Brasileira de Ciência do Solo, 31(3), 445-454. https://doi.org/10.1590/S0100-06832007000300004

Nicolodi, M., Anghinoni, I., \& Gianello, C. (2008). Indicadores da acidez do solo para recomendação de calagem no sistema plantio direto. Revista Brasileira de Ciência do Solo, 32, 237-247. https://doi.org/10.1590/ S0100-06832008000100023

Oliveira, L. B. De., Fontes, M. P. F., Ribeiro, M. R., \& Ker, J. C. (2009). Morfologia e classificação de Luvissolos e Planossolos desenvolvidos de rochas metamórficas no semiárido do Nordeste brasileiro. Revista Brasileira Ciência Solo, 33, 1333-1345. https://doi.org/10.1590/S0100-06832009000500026

Pavinato, P. S., \& Rosolem, C. A. (2008). Disponibilidade de nutrientes no solo-decomposição e liberação de compostos orgânicos de resíduos vegetais. Revista Brasileira de Ciência do Solo, 32, 911-920. https://doi.org/10.1590/S0100-06832008000300001

Pessoa Neto, O. C., Soares, U. M., Silva, J. G. F., Roesner, E. H., Florêncio, C. P., \& Souza, C. A. V. (2007). Bacia Potiguar. Boletim de Geociências da Petrobras, 15(2), 357-369.

Queiroz, J. E., Gonçalves, A. C. A., Souto, J. S., \& Folegatti, M. V. (2010). Avaliação E Monitoramento Da Salinidade Do Solo. In H. R. Gheyi, N. Dias, \& C. F. de Acerda (Eds.), Manejo da salinidade na agricultura: Estudos básicos e aplicados (pp. 63-81). Fortaleza: INCTSal.

Ribeiro, A. C., Guimaraes, P. T. G., \& Alvarez, V. V. H. (1999). Recomendação para o uso de corretivos e fertilizantes em Minas Gerais (p. 359). Viçosa: Comissão de Fertilidade do Solo do Estado de Minas Gerais.

Ribeiro, M. R. (2010). Origem e classificação dos solos afetados por sais. In H. R. Gheyi (Ed.), Manejo da Salinidade na Agricultura: Estudos básicos e aplicados (pp. 11-19). Fortaleza.

Santos, H. G. Dos, Jacomine, P. K. T., Anjos, L. H. C. Dos, Oliveira, V. A. De, Lumbreras, ... Oliveira, J. B. De. (2013). Sistema brasileiro de classificação de solos (3rd ed., p. 353). Brasília: Embrapa.

Santos, P. G., Bertol, I., Miquelluti, D. J., Almeida, J. A., \& Mafra, Á. L. (2015). Agrupamento de pedons de Cambissolos Húmicos com base em 489 atributos físicos e químicos utilizando a estatística multivariada. Revista Brasileira de Ciência do Solo, 39(2), 350-360. https://doi.org/10.1590/01000683rbcs20130415

Santos, R. D., Santos, H. G., Ker, J. C., Anjos, L. H. C., \& Shimizu, S. H. (2015). Manual de descrição e coleta de solo no campo (7th ed., p. 102). Viçosa: SBCS.

Sousa, D. M. G., \& Lobato, E. (2004). Cerrado: Correção do solo e adubação (2nd ed., p. 416). Planaltina, Embrapa Cerrados.

Souza, D. M. G., Miranda, L. N., \& Oliveira, S. A. (2007). Acidez do Solo e sua correção. In R. F. Novais, V. Alvarez, V. H. Barros, N. F. Fontes, R. B. Cantarutti, \& J. C. L. Neves (Eds.), Fertilidade Do Solo (pp. 205-274). Viçosa, Mg, Sociedade Brasileira De Ciência Do Solo.

Souza, R. O., Martins, C. C. M., Cavalcante, J. S. J., Sousa Junior, F. S., \& Sa, F. V. S. (2015). Soil attributes in agricultural uses and in the Semiarid RN-Brazil in eutrophic Cambisol. African Journal of Agricultural Research, 10, 3636-3643. https://doi.org/10.5897/AJAR2015.9983

Statsoft. (2004). Statistica Version 7.0. Retrieved from http://www.statsoft.com

Teixeira, P. C., Donagemma, G. K., Fontana, A., \& Geraldes, W. (2017). Manual de métodos de análise de solo. (3rd ed., p. 573). Brasília, DF: Embrapa.

Valeriano, M. M. E., \& Rossetti, D. F. (2008). TOPODATA: Banco de dados geomorfométricos do Brasil. São José dos Campos: INPE. Retrieved from http://www.webmapit.com.br/inpe/topodata

Yeomans, J. C., \& Bremner, J. M. (1988). A rapid and precise method for routine determination of carbon in soil. Communications in Soil Science Plant Analysis, 19, 1467-505. https://doi.org/10.1080/00103628809368027

\section{Copyrights}

Copyright for this article is retained by the author(s), with first publication rights granted to the journal.

This is an open-access article distributed under the terms and conditions of the Creative Commons Attribution license (http://creativecommons.org/licenses/by/4.0/). 